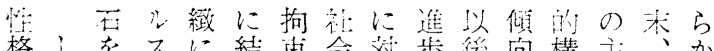

格しをスに結束全刘步徭向構主、加こ

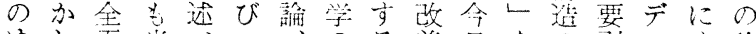

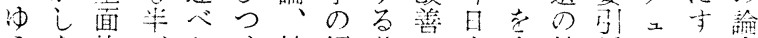

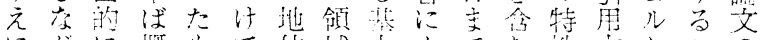

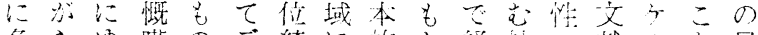

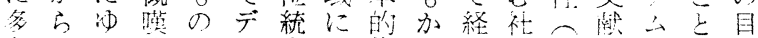

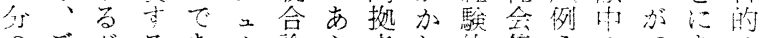

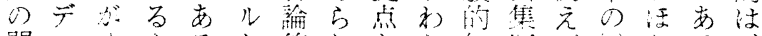

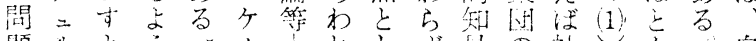

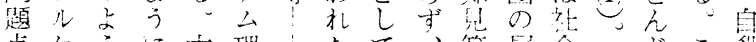

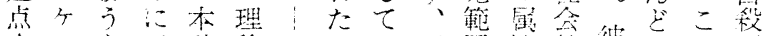

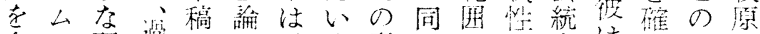

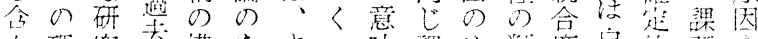

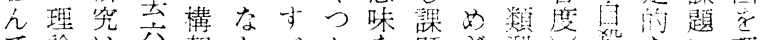

で論は宍想かべかを題ざ望し郋なに理

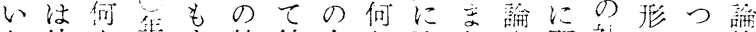

た彼も閏ま特結自ら取しを関赫でい的

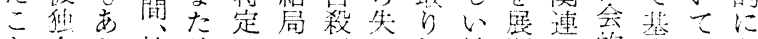

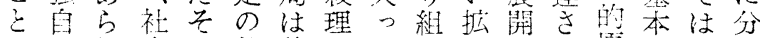

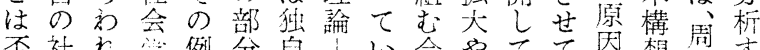

否社京等例分自: み会ての外をの|学な社説を智る 難学い自で搪経アいの会る明特示の放

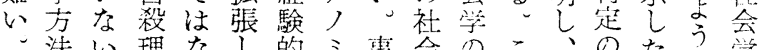
法い理なし的ミ事会のこの、京社たに学

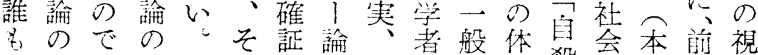

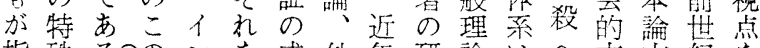
指殊る更のンを成外年研論法へ文文紀を

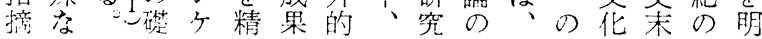

社
会
学
に
お
る
る
臬
理
論
の
検
討

せでのの学含ついしものので社でか方 引あ状い各のさのなかの認あ会必口る きる態う名観机類心しに識り的要たょ

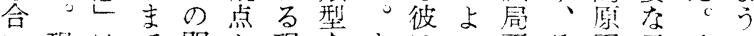

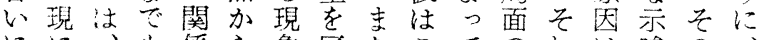
にに、先像区たこてのれは唆の、 出デ具なを指の别、の説限は、注た彼 $L=$ 本い具摘な $L テ ゙$ 特明定冬社直めは た的こ体しかたュ惟すは観会接にこ 々に方的たに息る的構引彼の 例么ぞでな点、こケ体し彼に造きの現 えものあ行でいのムのうのそ中出理象 ばこ集る為非く区沬観い提のの势埇の の囦がの常つ別集祭う唱成種な加原 家状に、次にかは合可棁す員々心ら因 族態も自元重の、体能準るののひはを

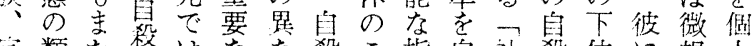
宗類产整はなな殺こ指倪社殺位に視人 教型どを取意るとの標殺会の集と的行

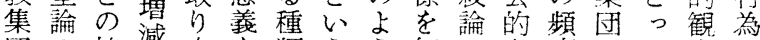
団の社減上を類うう何にな度のて点の

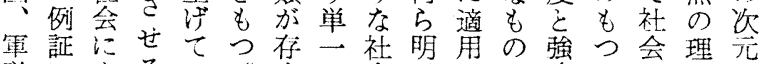
隊にもるい。在の会示しは度一学論に さ存種なし夺用属的たつ等の分お 職ま在名い加る語性にこ栱の扱析い 業ざししし事の規とに定社圾をて 団まう社実も有定に社字会引進追 体のる会彼をと效し会る的自め究 集も環は社になてる的。特殺るし 
自 主

殺容(1)

為自

次殺

決のの

定三社

関の的

与方原

寸法因

るのの

諸何究

因鸱明

子少

のに目

な立的

加 0

でて

特淮る

にめ経

社方験

会れ的

的 $\tau$ 調

因き查

子た注

に

注っ示

しはま
古示し定通含解

に社向のの々集当市

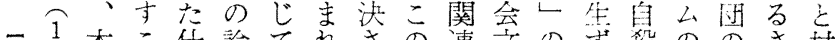

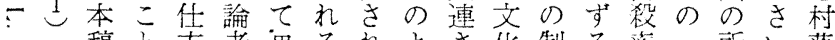

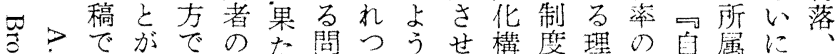
る?てかでのた閏つうせ構度理の自属に

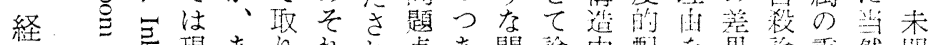

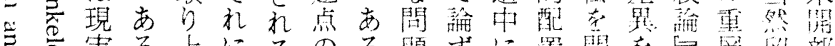

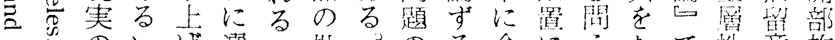

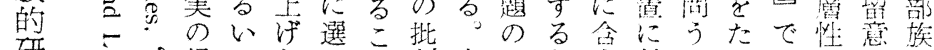

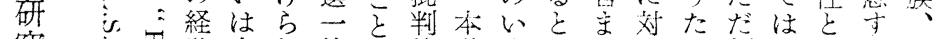
究田験本机的に的稿くいれ古め類むそ心国

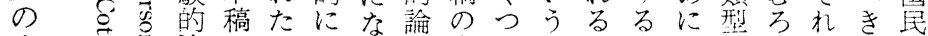
方言导資ののはろ評意か課自顧はのんぞ事社

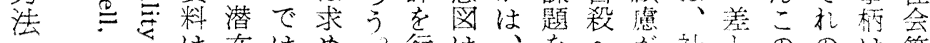
○は在はめ。行は、をへが社とののは等

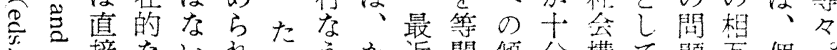

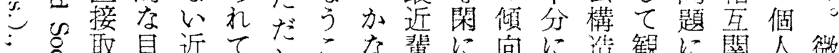

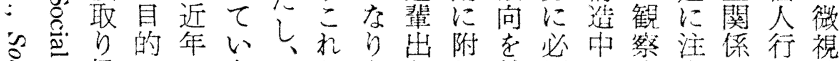

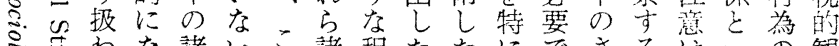

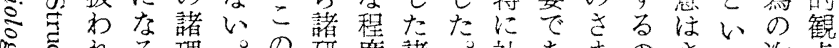
祀る理。の研度諸社あまのさう次点 氙なの論必論究心研会るざでれ点元で

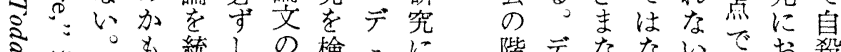

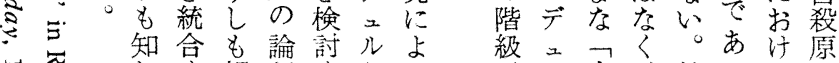

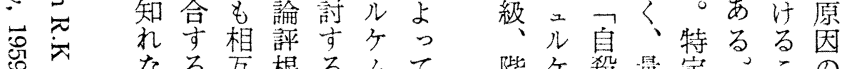
可なる互根るムて 階々殺量定るこの ○、構に拠過理徐層么へ的社デ沈

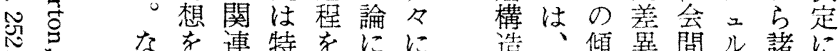
なを連特をにに造傾供間ル諸に

る的多体因な個居見を圧れ用っ関にはのでるれ計そ ○わ数で子汀人住守種力るすて連関直はあ视る的れ 理把れの個はれが、る々なでる問に係接個る鉑自事を 論握わ因人多ほ属家このいあ特題拈注別者殺奏行 のしれ子の元な炙族々項しろ街はいた目的前方率々為 価、にが自的らるのに目傾うや、てとし事渚方のしの 值単と個殺でな高貧よに向。条こ具思な例の法差て次

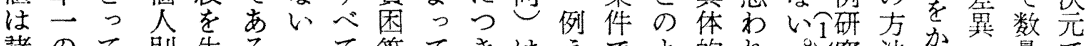

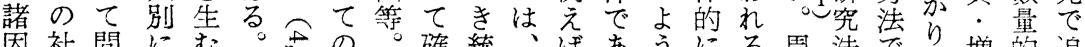
因社問に导の。確統、注あうにる周法でり增的追 子会題特汪し集微定計通方るな追種知で、に減に究 の学は殊ほ加団視さ的常家。個究々のあほ微に観す 価的、に十七倠的れに族別さのよる視関察る の理こ作分こ河なる洗な複環計的れ因う。中的与し方

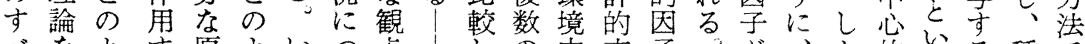

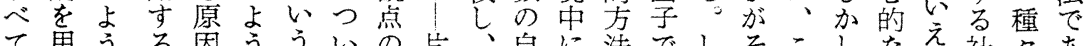
て用うる因うういの片、自に法でしそこしな社々あ

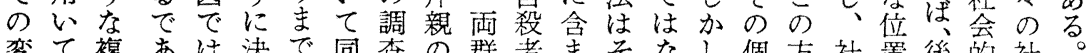
変て複あは決で同查の群者まそなし個方社置後的社 動そ数引な定も一で死間のれれく法会を者因会い をののういさなのは社ので学占の子的ま 如説因一任父有族負の多会生ははめその部立 何明子息た、方家の意と因決数学活特各てれ究類つ にに相殺各そで族失差非へ定自の経筀事きは明やは 小当互の因こ因以業の自自の殺経歴個例た明に下、

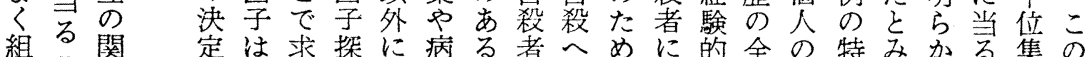
みこ連に、め究お蒻因ののに共研状自称なに方団現

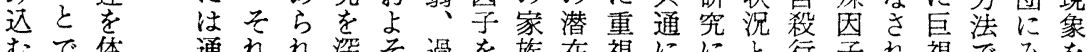
むで体通れれ深衣過を族在視ににと行子れ視でみを かあ齐常自るめ諸密発と的さ作との為にる的あら統 


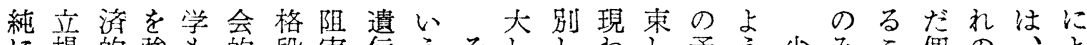

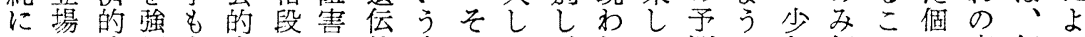
はの決调自文にし的事のて、れつ測に年個の及事個っ す結定す秏化進て素情理進個てつのと非別よに例別て

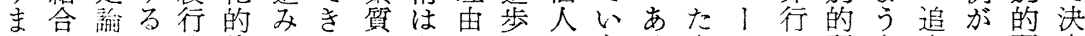
さははに為諸、たにさはしのなる研な究い研定 れ、亦至の条初事求ていて自い。に分究多さく究さ なあ活り説件期情め京くい殺。し役と野に元れつにれ くるを、明のの肪るくつる行まか立方に寄的るかおるる す意ひ前に重こ指偏とかと為たし、せ拈与因だのい る味そ世精要の摘見しあはの、、るむけ因て自 理でめ紀神な派で乫てげ思過各自範兴てるをで子普敉 由個たに医意にき正もらわ程因殺例ク右で予あの通行 と人。一学姫みる5当、机れを子論を夫のあめる特認動 もの自時やがら吼な例るなっ理がで提妻方ろ理。殊めに な行殺風心益れも経え。い出猃個は供で法う論社なら関

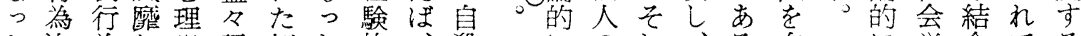
た次為し学認極々的、殺にのれ、る侑に学合てる 元のたの識端も調この説生に進瀿確はにい方 こで源二成さな、查の個明活匹随特に定個よなる のの因元果れ前最へ現別李構敵者に用守別っいう 観原分論をつ提近の象的る涺すの後いる的て。な 点因析的取つはは意の凟 で須のなりあ全精欲原料 は明基社入る全神を因の 老本会㣗呚放医極を収 当加的的る一集学々専集 然えななべ方さの最らが なっ二いき然研近二至 唯てつしこ社、究ま定難 一中る間者た 般にほには代 分めの当の者 析る研の方は の意究效法、 枠味は果悬周 組を未を非知 ら単の経と会社もでのと

も識だ約行の

とに決同理 心特定方論 う殊さ法的 目なれで分 的結るは析 に合事、の 関を情そ必 し生唯机要 て守た毞性

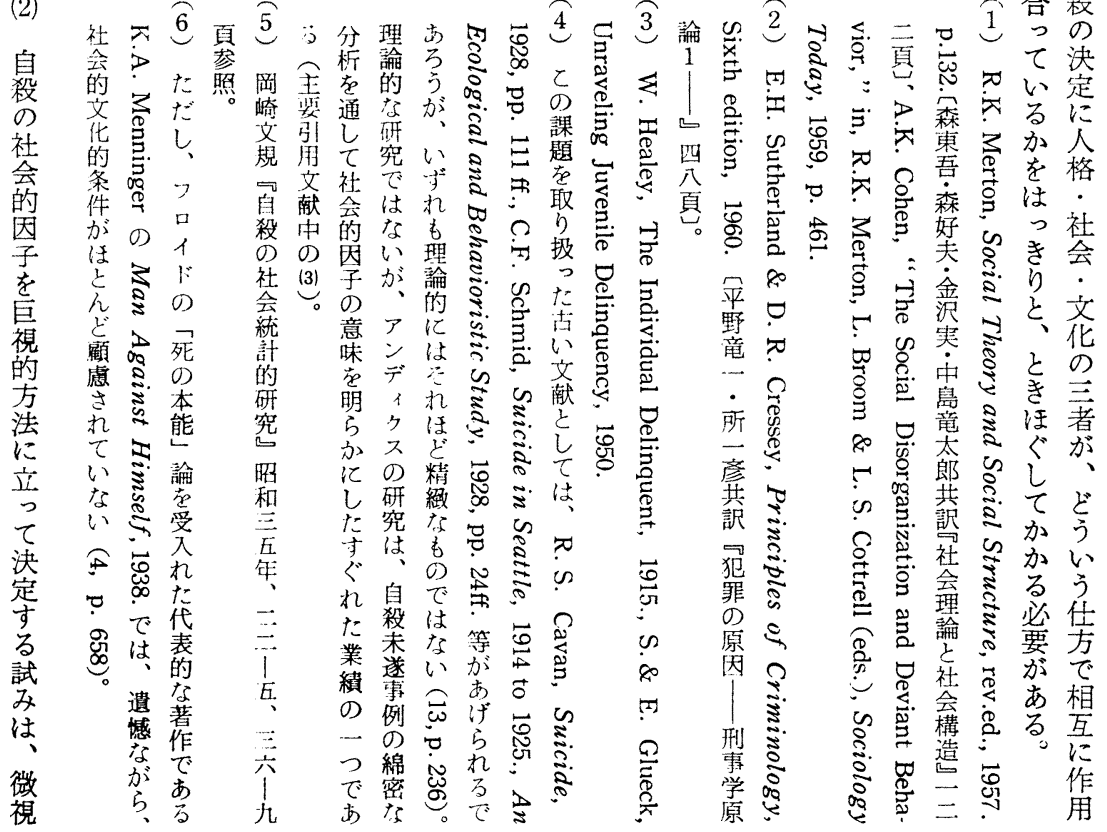


のはづにすが結、釉全実别欧吕なな!るっののの的 相、け影に、び今の泣く渚州る意が、著た二指研な 関自る響過そつ世解け無、はに活義らモ者が般導究そ

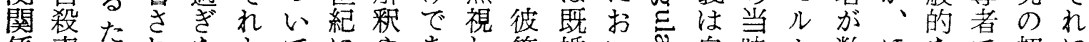
係率めれなとてにやあし等婚い兽自時セ数ほなで初に をとめるい同見入もるての者て导殺のリ多と統あ期比 み特に事こ時出っル。よ多よ、染事、くん計るに心

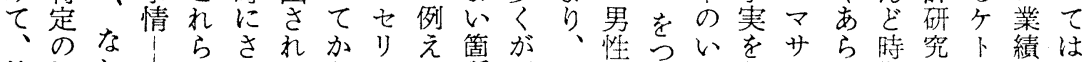
後社お|のらるらにば所認都はとく記リわ期のレをる 者会主つ量に地以及個はめ市女淩録稀なな1あか の的とま的進位後る人、た住性指のにクて同かやげに 統変しり事ん部の進のかと民皇摘統留等いじのゲた起 計数て・実で類研化自よこはりし計め々へるく特りの源

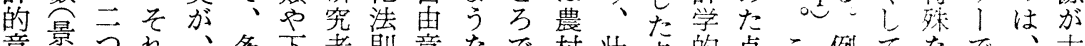
意晈つれ、多下者則意なで村壮点的点こ例てなで、古 味齐のが社数位注に志斉あ售年に斉にれ息的あ創々

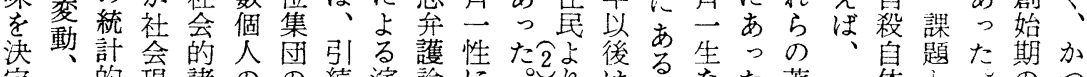

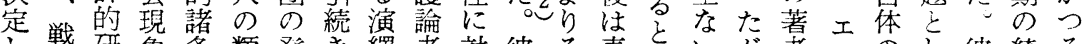

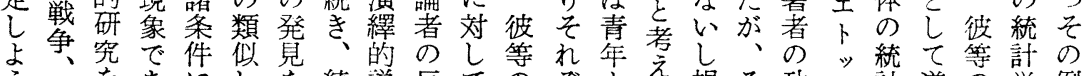

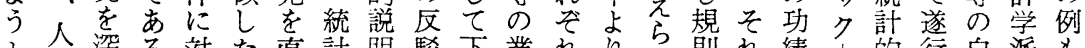
と深る対た直計明駁下業れり、れ則れ績市的行自派も

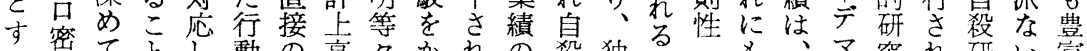

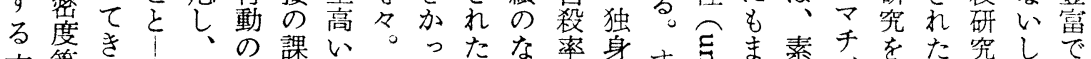

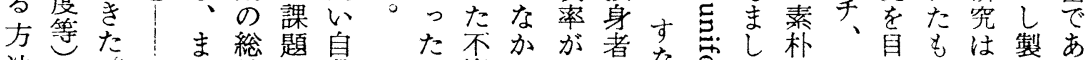

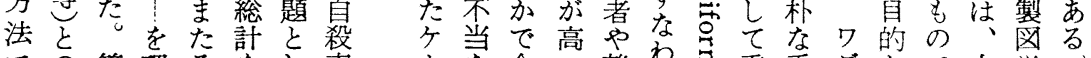

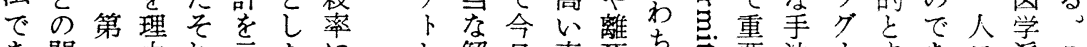

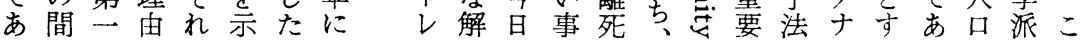

化う查なのはに理し 熊も息の戛いも供経か方がる にに代い息、、論か心学あ殺存殺不がと経部し法非 先

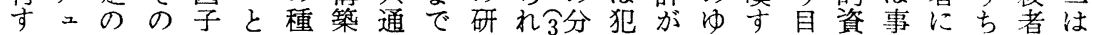
るル社研はものにのも究る野罪実える的料実属後の、 素ケ会究個ら研何欠なも。の論際によをのにす者間一 材么学吕々し究ら陷くまそこやのこう離收関る数に定 との的社ばいの関は、たれ非数れにれ集古研つ生の

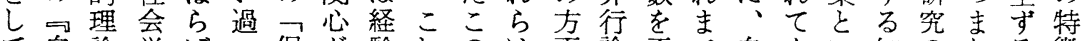
て自論学ばっ保が験れのは面論正で自もい知のりる徽 意殺に的らた険な的ら系系のの確大殺、う識成統各な 味論指とに解統い事の統譜開場にきのそ作の果制頻い 己向心観秎計こ実研の的拓合あく科れ業蓄に群度し けはしわ祭を的との究延にに以らは学自は積は法々条 る、てれさ埒説で発は長す独上わば的体、に非はを件

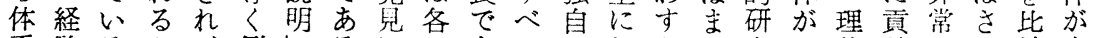
采験るた、例しるに名ててのわ加究一論献にほ較自 の的こめ各がへ乞主独る統価れ否てはつのし注ぞ夺殺

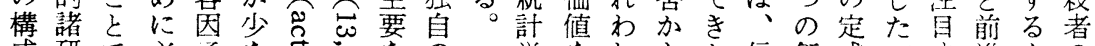

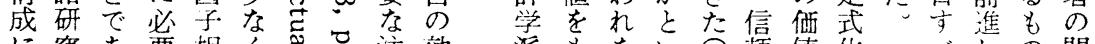

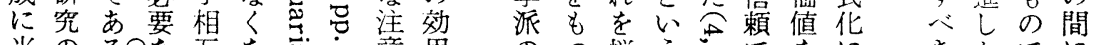

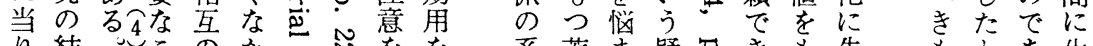

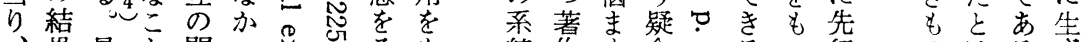

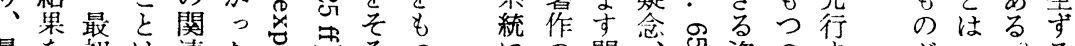

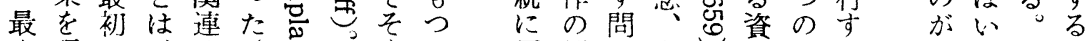

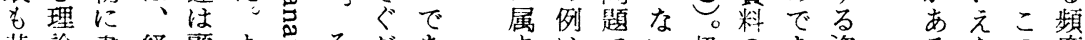

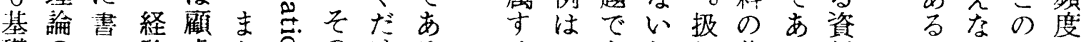
礎のい験虑たすの污ろるいあしわ著る料ないる

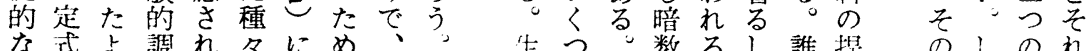
な式よ調れ々にめ、生つ数るし誰提ののしのれ 


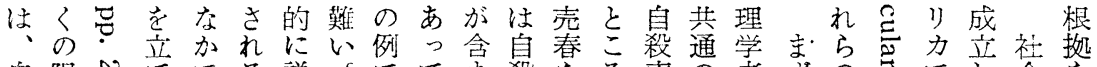
自限心てでる説二でて立殺なろ率の者夺の劣でし会を

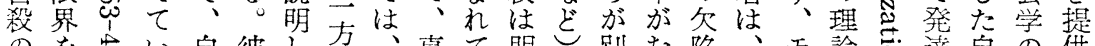
のを巴心自彼し方、真て明し別む樎、モ論它達自の供

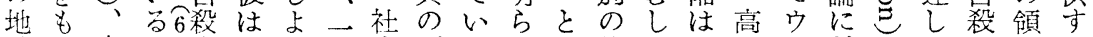

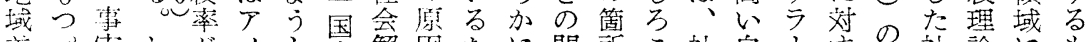

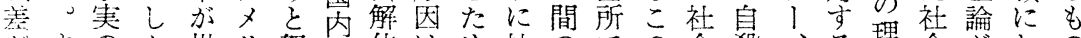
だすのか世リ努の体はめ社のでの会殺、る理会がおの 汗な説し俗力め自論実に会統は属解率土若論解全いで でわ明、化国る殺は証、解計、性体がリ卉で体くてあ

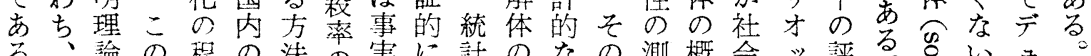
る、論の程の法の夷に計のなの测概会ッ評る。吕い= 第々分度各の地に何的結相他定念の価 し $こ$ 析 たにて方正域つ的い説示現関社能不体メ赤ュたで がこは法比のは分て明さ象係会な明にりしルすは理 つの゙は例自ポ布のされでが病指確よルてケ祭な諭

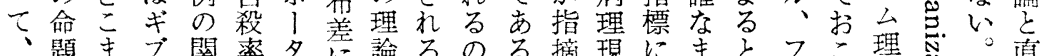

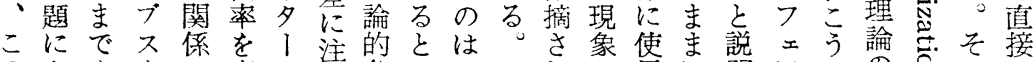
のよももで広フ自分こたこれた用に明アへのらのの 理る部指增㲸 1 し析ろんのて犯さ用しり岕論さ代系

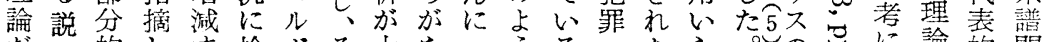

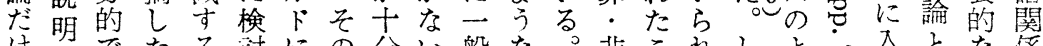

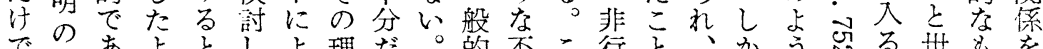

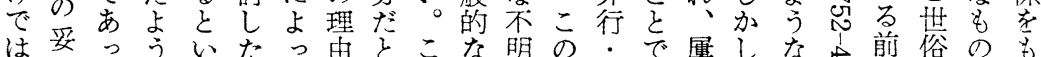
世当てにう報てをは狆関確場離あ多彼社参に化はた

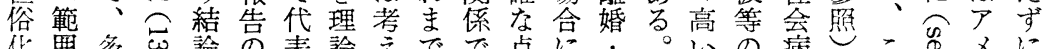

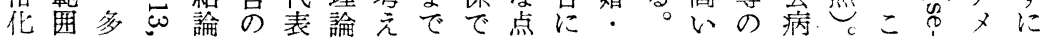

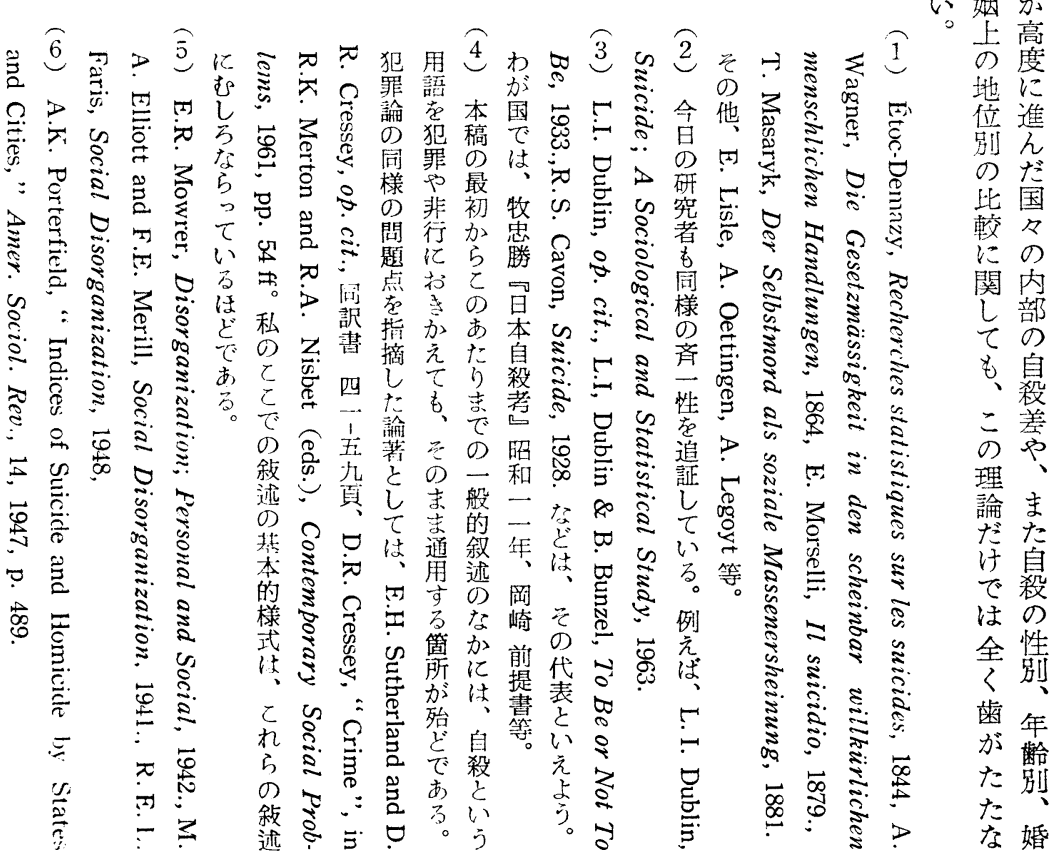




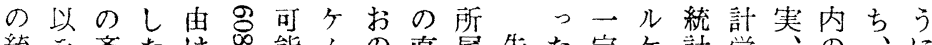

統を斉たは舟能么の直属先た定ケ計学、の、に(3)

台理一特単志にがの接述。の公学的な人そ自

度論性定な。すわ統の婚し 社が者なら口の殺 ゙ニ二

に的がのるそるれ計因姻た苓自が斉び学立の二

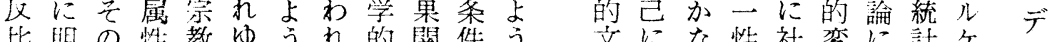

比明の性教ゆうれ的関件う文にな性社変に話々厅

例ら他辛えなに辛係、に化課りで会動当的么几

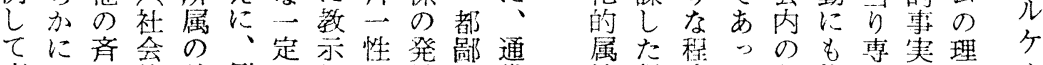

変し一的差例のし注兒の常性課度た各拘らで論么

华た性統買え社た相に居の題ま地ら注あ構理

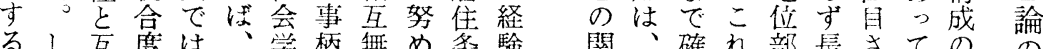

るし互度は、学柄無め學験関、確れ部長さてののの

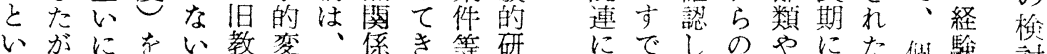

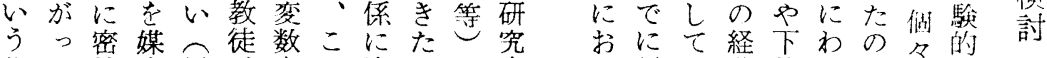

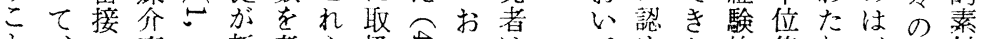

と、に変も新考ら扱さのはでた的集り、自材

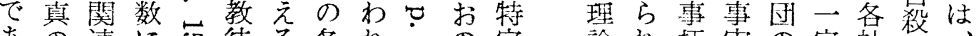

あの連に包徒る各势のの定論れ柄奏の定社事

る法し用

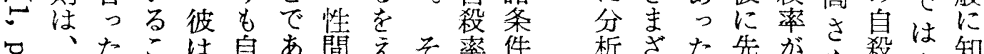

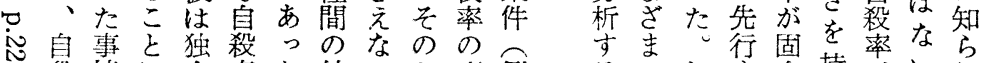

氙䄫情に自率た結いた弯例るのし才有持がいれ

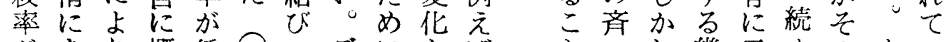

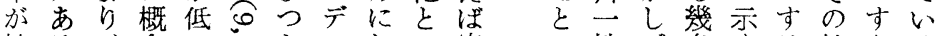

社る、念心すきょおの宗で性テ多する社なる

会折こ华理导を几の間派委むの統事会わる

ケをる心自が的れ的形で析とを切の異下理導合あ

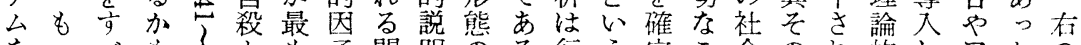

をっべも心とも子問明のる行う定こ会のれ的しなたの

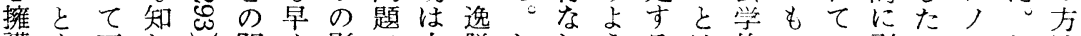

謢も不れ澗く影で十脱しわうるは的のい引こミし法

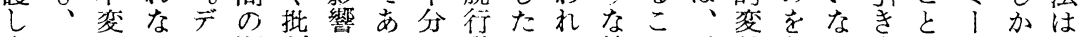

なことい=関判のるに動がた特と擞各い出がのし社

けの考諸ル係しみさうでっが是でブと集。さそよ彼会

れうえ因子はたを例かはていのあ関合むれのう自学

ばちて子ムデと切えがないこ社るも連体した第な身の

な最問自ェこりぼいしデの会っいさのろ指一媒の自

ら後う身儿ろ離、難に二両的のうせ属デ標の仝論殺

なのと都はケで寺与い特ル者属よてて性ュで点変議分

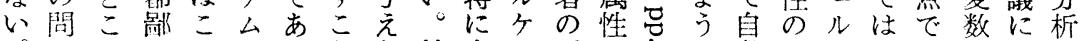

。題乃のの号っと第自么因とっに殺測々ああをはの

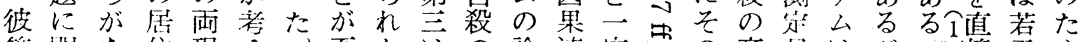

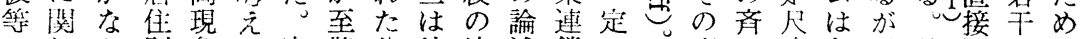

のしか別象た実難公彼決述鎖の第変一度各、確测のの

関てっ、の注な式の定かに自第数惟に社そか定疑基

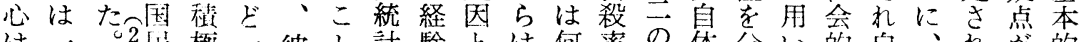

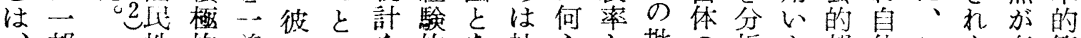

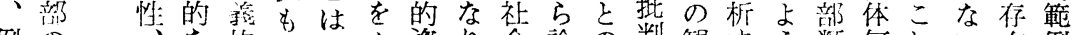

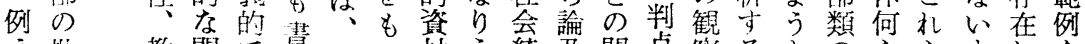

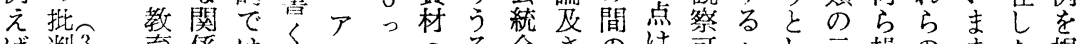
ば判了弆係はよルてのる合さのは可たし示操のまた提

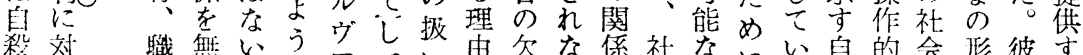

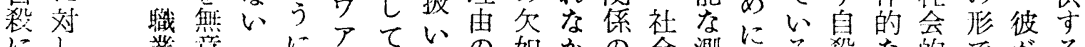
にし 業息ににていのの如かの会测にる敉な的でがる

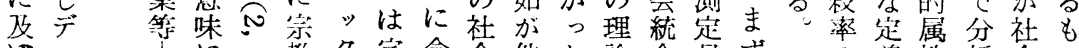

浔二に它教ク宗含会他た論合尽ず一の義性析会の

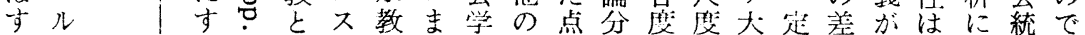


物杸的一の制での生自客的点的はのの批せな原 デののに性うししは自因殺観事周に変、社関判たが因 二観経例はちう彼な殺素率的実知あ数マ会心点分らと

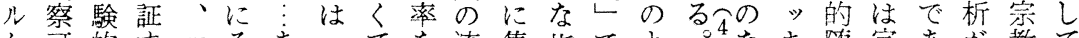

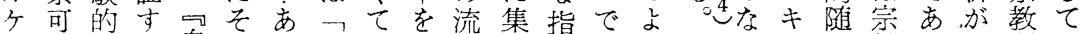
么能資る自のるこ主生れ約標あうう加伴教る必别の

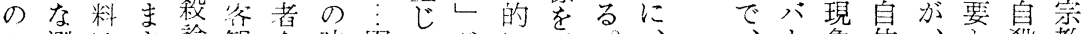

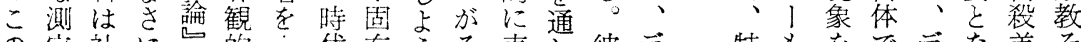
の定社にし的交代有うそ表し彼デ特もをでデな差そ

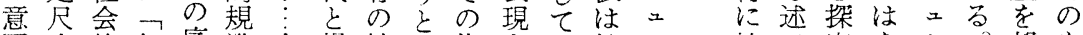
図度的好序準自場性专指さ把社ル社へ究なル。都も

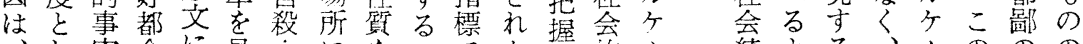
、し実合に見主にを集でた势的么統よる、ムののの アてになも出 $\vdots$ 応有合あ集る事に合うこ特の分居追

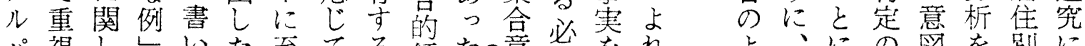

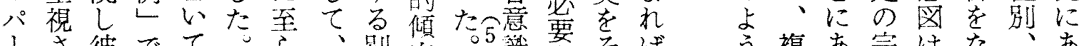

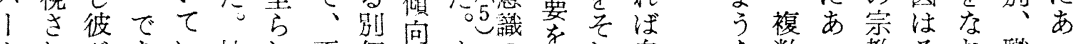
卜れがあい社し不個はすの棓れ息な数っ教そ方職っ もた理っる会め同の李状説が殺六のた所れざ业た 指。論たよ的るの独わわ態が顕の定方。属とり别

摘的。う自傾合程自個占热現社 の法彼がはに等そ

しにしに敕向し度のア、つ、先さ

た構た、率しを事の各ま自れ的

よ成が社のすも実単社り殺る随

うしっ会示なっ位会社論個伴

にたて的すわてでのに会的人現

自特、事統ち諸あ単おのでに象

殺定種実計個るないつは外は

率の々を学拘人つるて自社在二

に構の実的束をた総二殺会的社

関城自証斉強它和定発的会

変での自明し及の 数設自殺らたの目 の定殺頻かと諸的 み可論度に心条の が能論を別う件た 着なの高でのとめ 目他特めあがクに さの殊るる彼口は れ社な理。等 $又$ 当 た会点由彼のさ然

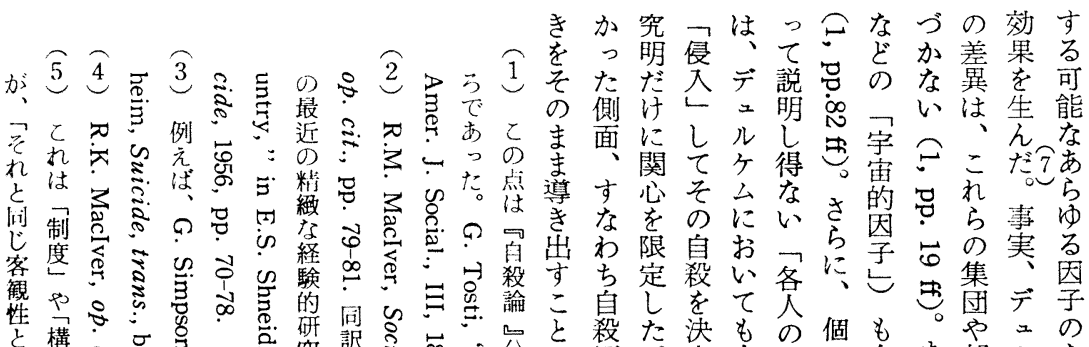

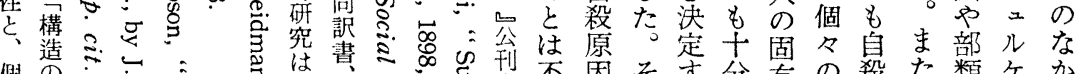

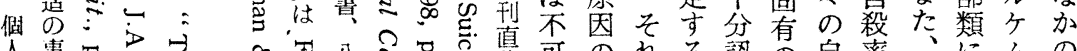

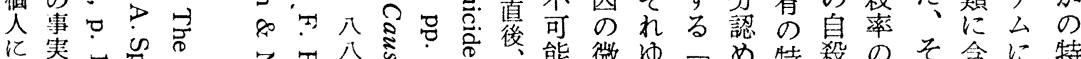

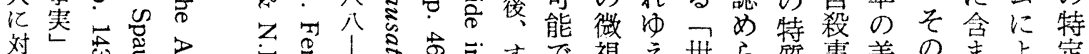

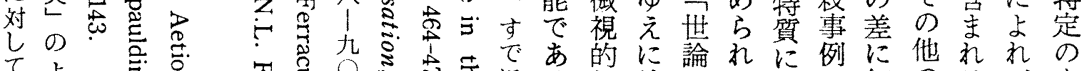

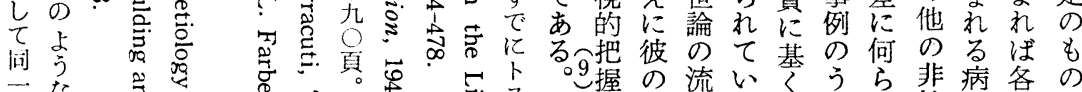

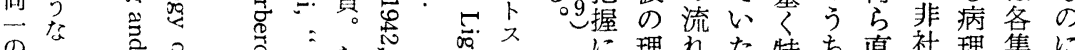
品安的小心

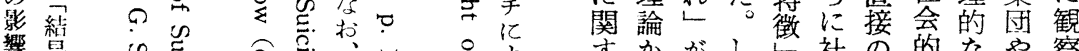

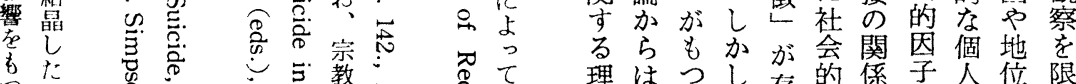

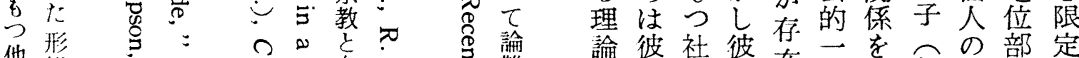
他態

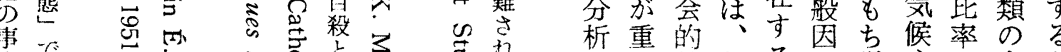

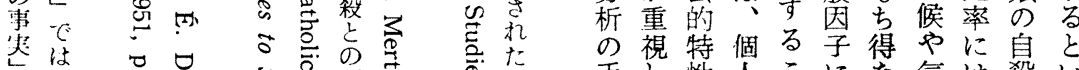

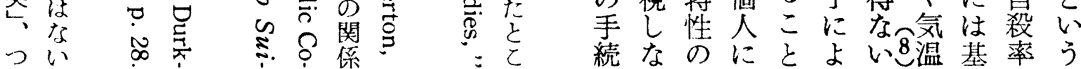


にさあるか命主し

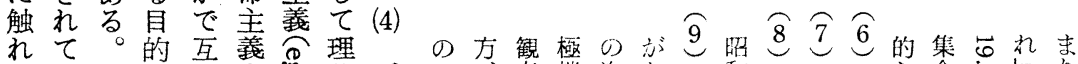

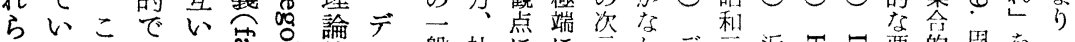

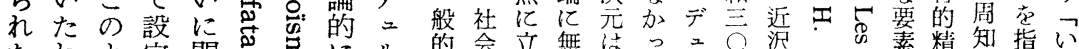

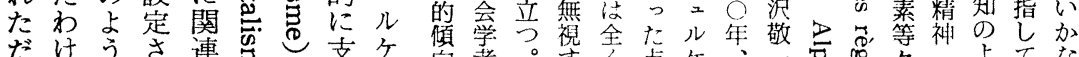

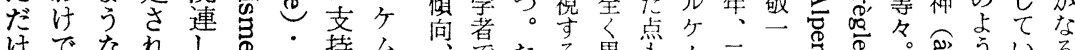

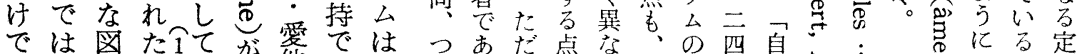

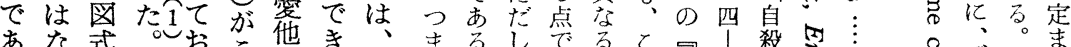

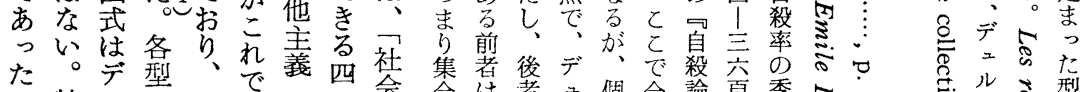

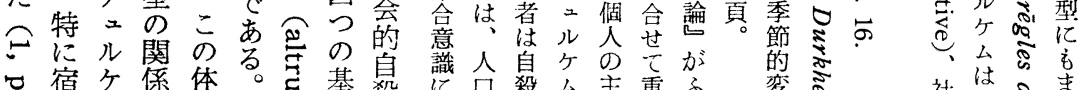

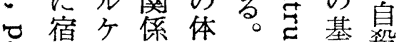

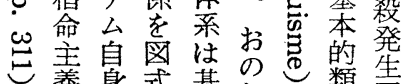

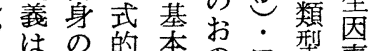

乙彼論的本的の型素

加述示にはノ妾流

しよ中せ集方市流

同っに拿っ意の令た告

で梅导揭識理总す相

はくしのの論怘な異

こ簡を図型的可わな

の単明のを図招方

型に確上記式上、方

に脚にう述のび利向

他注示で悉な宿己と

に品殺么主重ふ

そ中のは観視?

のに原精的元

原一因神にた動

因定学分意心機

党の無梠図乞と

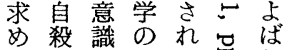

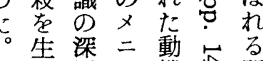

生㳪之動点問

志涪の苍題

5 理 $T$ 意离

と汇な義崖触

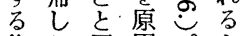

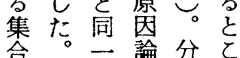

含他の分析

動

社は字ま

に会と市的の

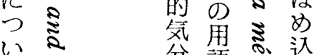

て分語交望

$\neg$ क

ล. 々 इ れ

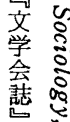

第

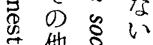

程 社

名会

筧的の

第 ?

の卓兽 自

号 8

本た質た流

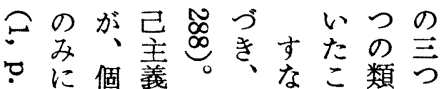

心従人前他わと型の

岂うが愛者のちはを型

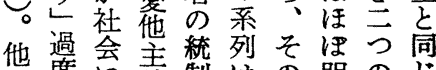

方度に義制はの明の艺

愛個棸名相社つ方香重

他人る名文会のなの性

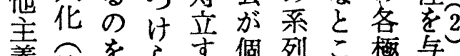

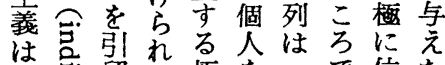

は恣留た極を泣で位た

社念め。は統個あ置デ

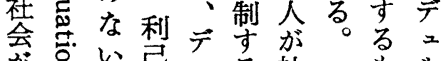

令官以呈二る社它儿

個怘た義ル様会のケ

人哥め羕尔式的公

過导に台にが結售に身

度命二結上根合対艺

にさ自合先拨拿立の

密の我のてとる 的図

接状茂弛そな様にの

に態自んれる式把よ

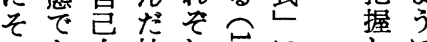

彷る身会利す基礼四

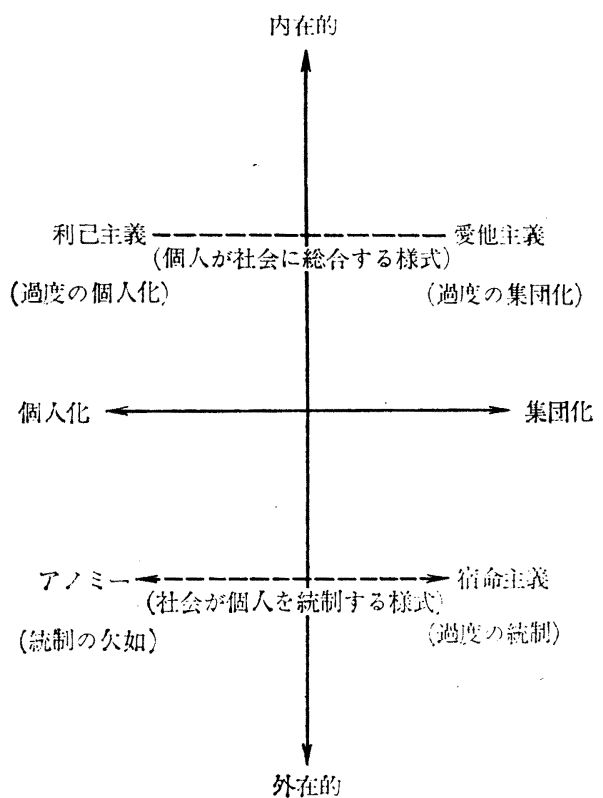




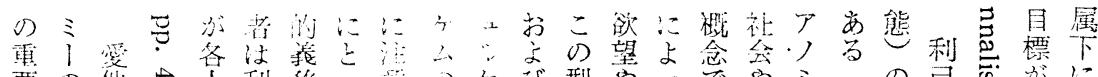

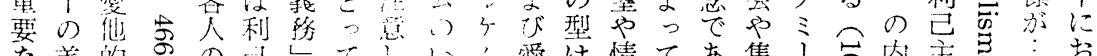
な差财

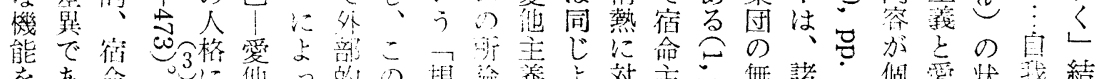

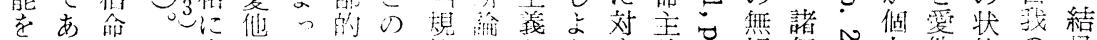

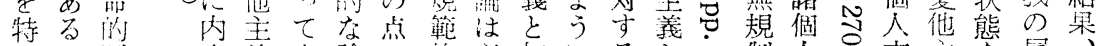

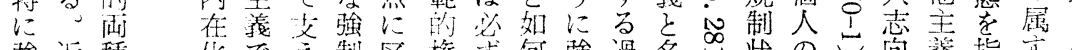

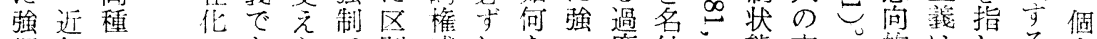

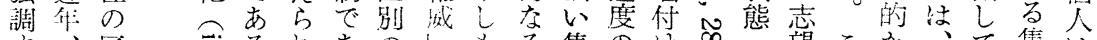

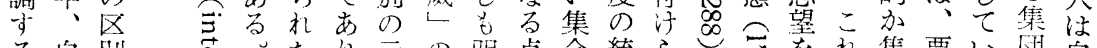

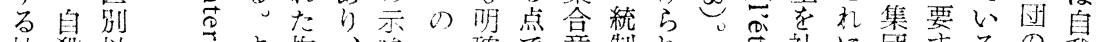

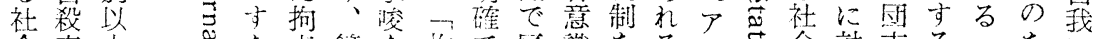

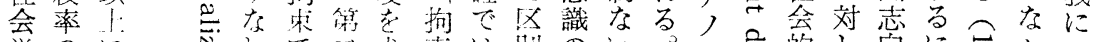

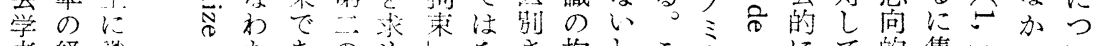

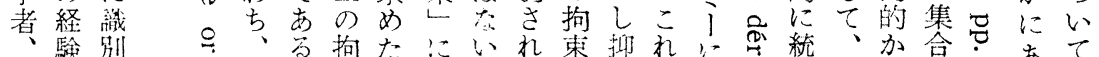
例的困

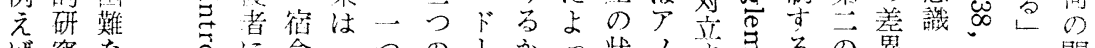

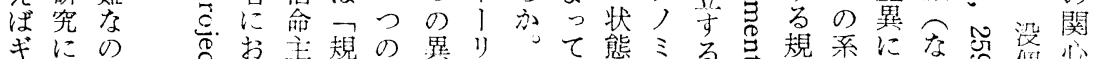

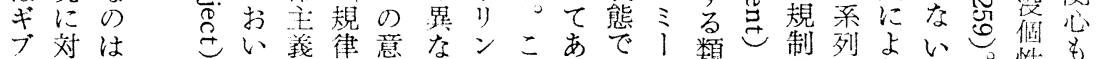

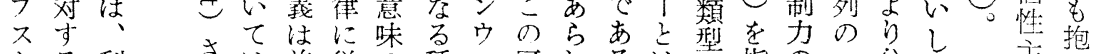

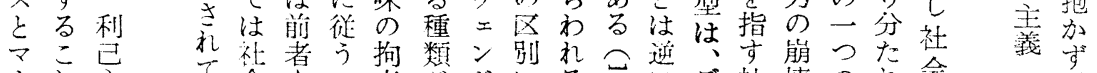

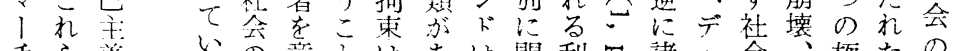

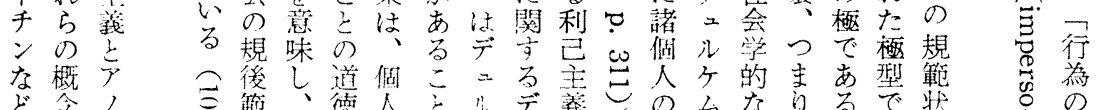

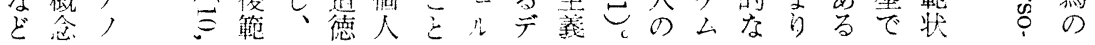

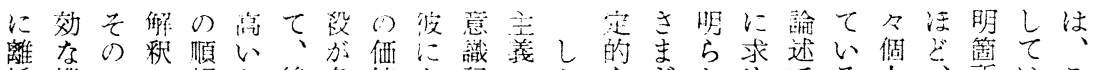
婚機こで相た後多值方記の文なざかめで忌人所はこ

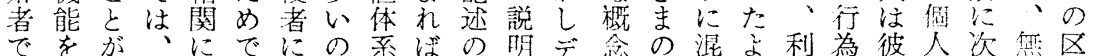

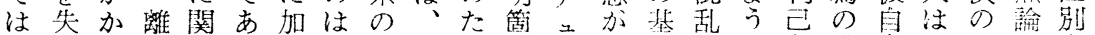
なわつ姅守るわ、界自め所,用礎さで主集身飞よこを

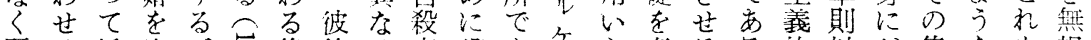
既る婚容デち集等る率設もケ引考る当的以た集なも視 婚結姻易工导合が内が定う公狆虑もが自外团諭正し 者果がにル?意集容旧しか自てしの、殺のしに述当よ

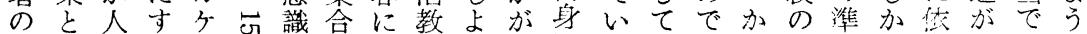

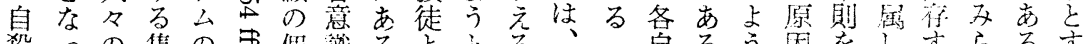

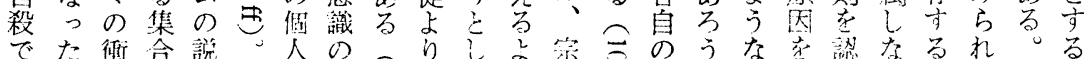

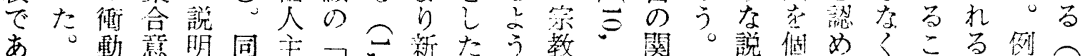

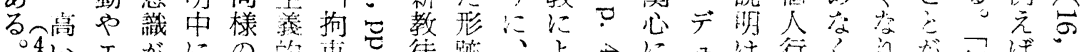

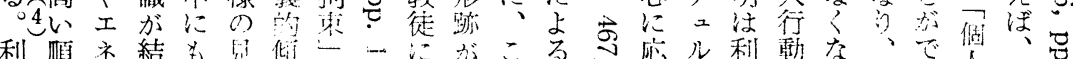

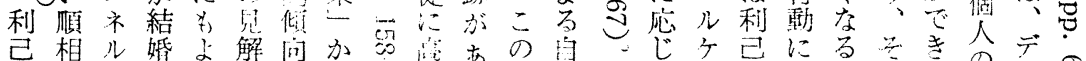

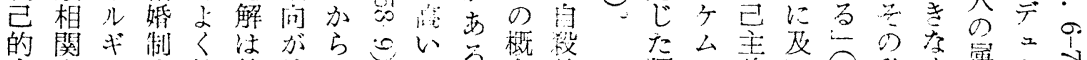

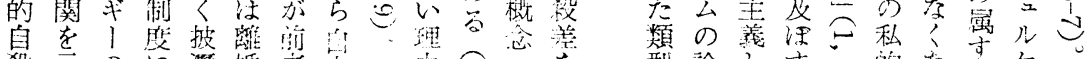

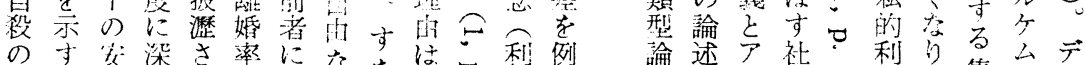

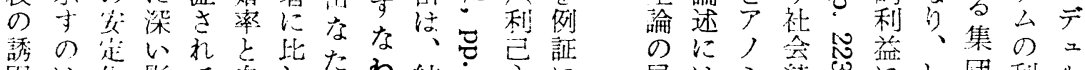

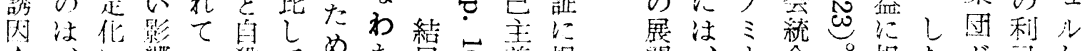

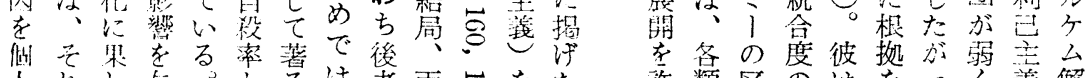

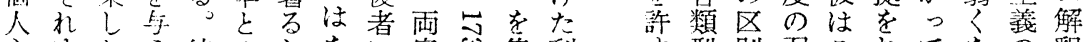
主沛たえ彼のしなに宗集利方型別弱こ抬てなの积

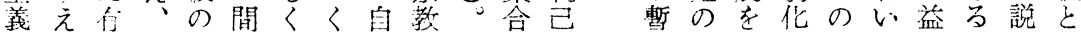




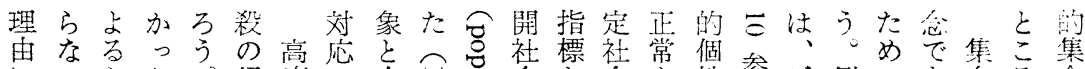
にいとた。経度で自引芑会と会な性参デ例にあ合ろ合

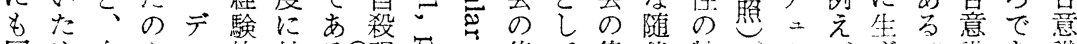
同め自むこ的抽る7現? 集て集伴特しル注ずす識あ識

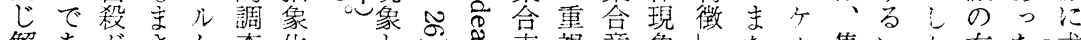
解あがさケ查化 と过表視意象たた六集いか有た求

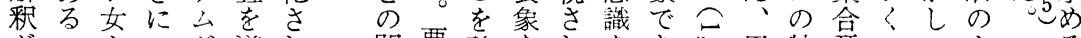
がよこ加導礼間要確をれなある。

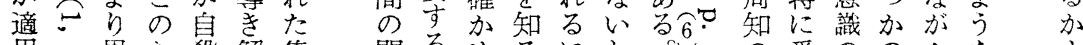

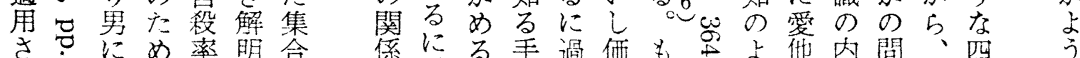
れ心多での专意 た岕いあ性る識 こ理る差なの

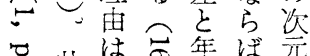
导壮宣年ば元 年者导差豈注 导贞後占理 卢注 し青宝参を理し し年共照属告ぞ

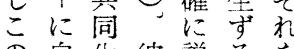
の自生彼説る 解殺活の明こ根 积㤎に説し亡拠 多加明气之注

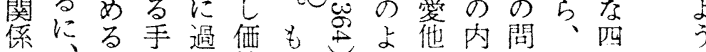
は二必引き值しなう的容題そつな 多の学々く采よの彼敉自予の種积

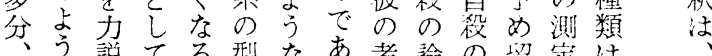

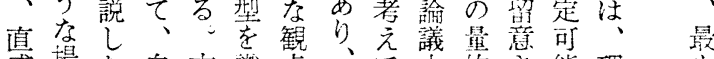
感場た息文識点、で中的さ能理》 感合の教华别唯自はに変れな論強 よにもに人青過殺示化な標的く

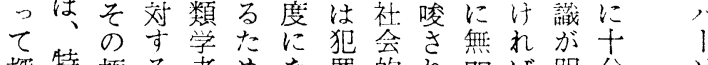
探特極る者めな罪的狆関は明分》 系定端住ののれと自て係なら支方

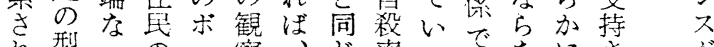

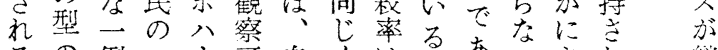
るの例一ナ可自くは市いされ継

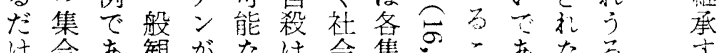

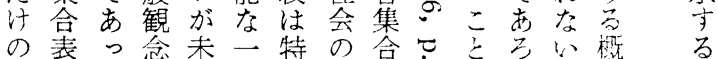

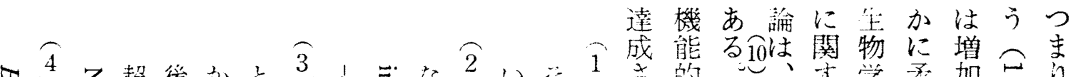

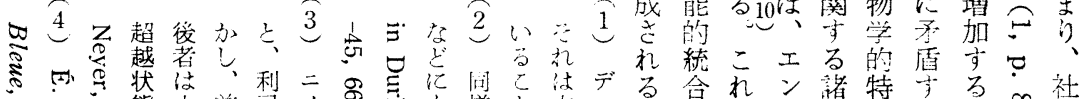

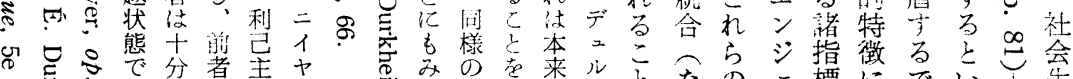

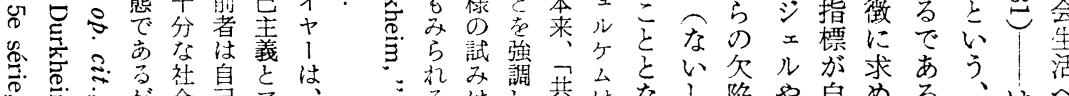

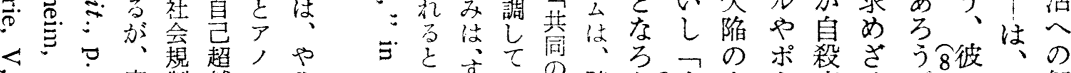

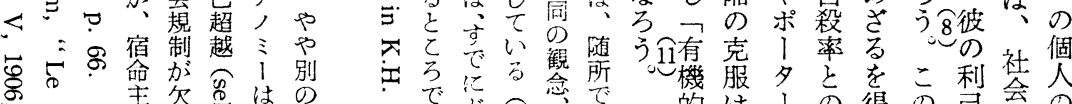

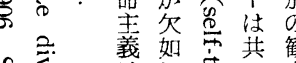

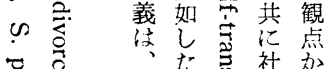

导交社点

品過態怘会品

も气荌管団者

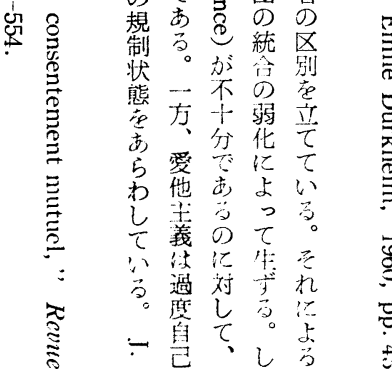

せ去占例信备

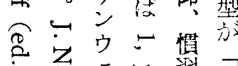

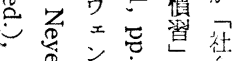

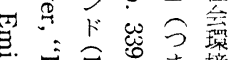

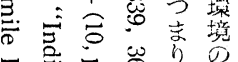

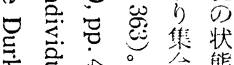

离总富 意態

的は1 の得の悡会人 漸、フ間なた的集包 带社1に方め息の絡 し会ル何っに殺統度 の統ドに占た彼論合に 垐の品確它結基度此

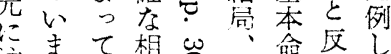
注まて想岕性題此て 白つ揭を㦈例自 しの娆社やたの敉 た次らさ会年こ関は

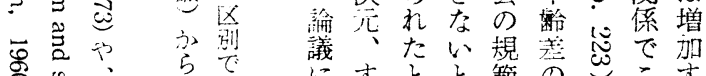

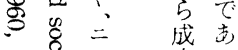
に寸とと範の可亦 よなこい的原にのる

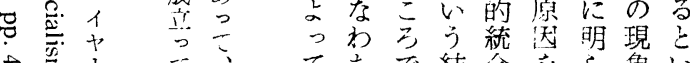




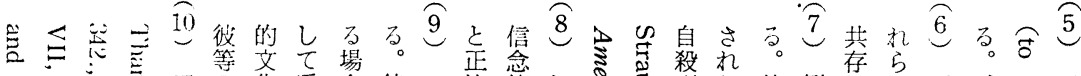

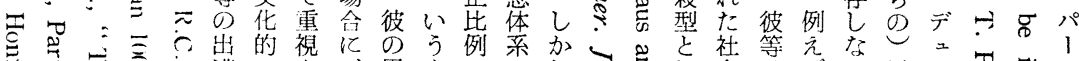

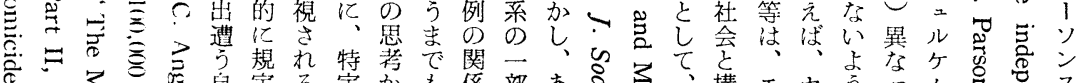

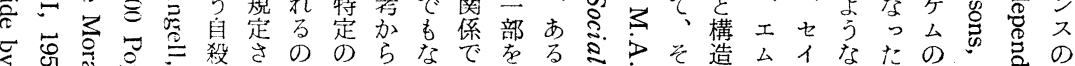

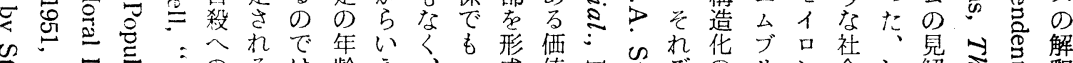

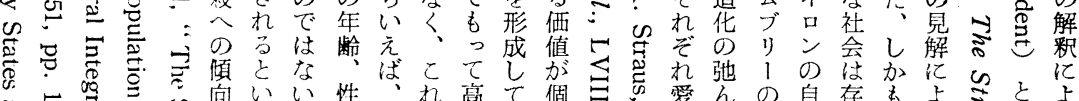

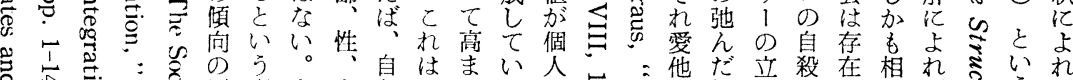

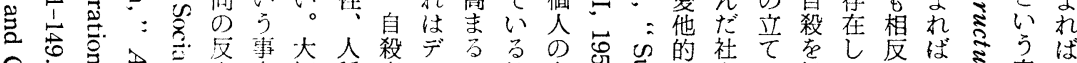

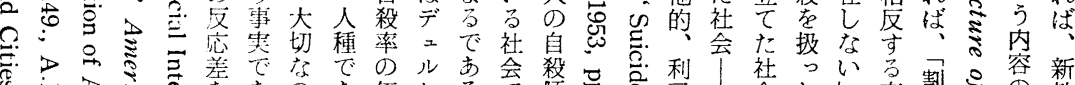

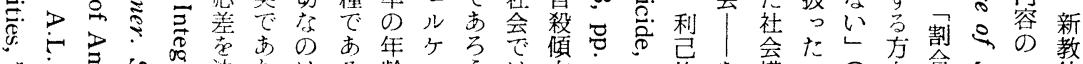

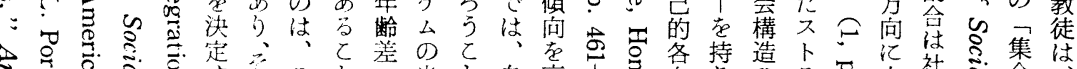

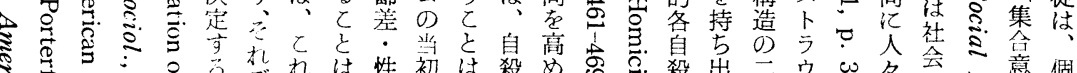

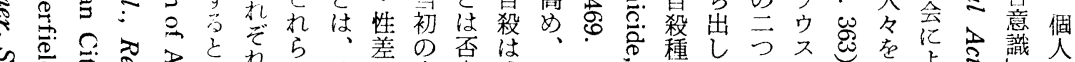

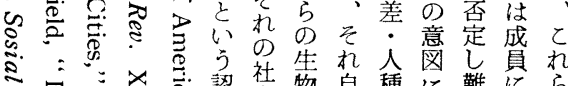

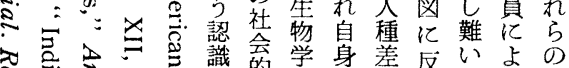
施

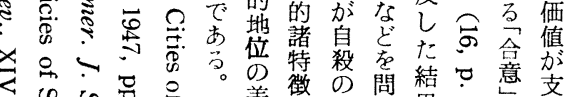

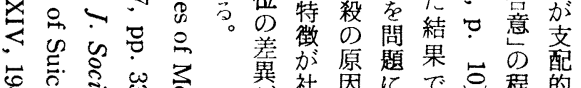

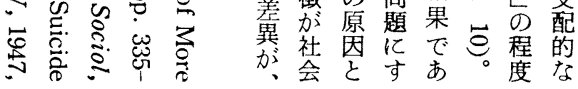

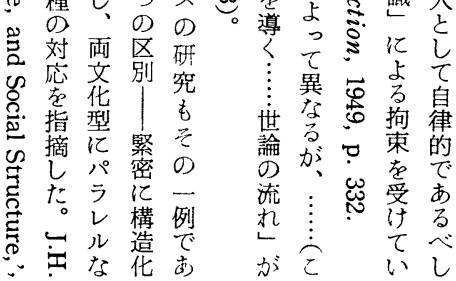

論ンのがのめぼるる一型

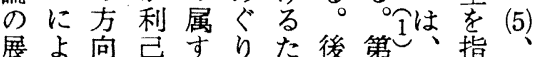
展る向吕号特め後第集摘デ 論各精自社ににのは合しこ 点共緻殺会集概方、意てル を著な論集中念向集識以々 㥂研中団的的の団な来公 くあ究にのにに論成い穴 らる例立統発構議員しこ社 がは合展成はの社の会 異心展せし、相会類環 にンへ一にしたテ互の型境 す。ン般反集二依規庄に る。可少比ら団儿存範主含

題例れ的分的状㳊至 たと乞した属公活態三れ だきて性䨿動の種のる 1 0 葳の悡次類方自 こ のお包る開会愛にしでへ 両よでと論的他注て記の 著びあ心拠統的目区述傾 注ギっうは合自し别さ向

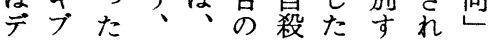
二ステ自程の類るてに ルと近二秃度原型方き四 ケ年儿加了因論向たつ ム、のケ個をでで。の 理チこ么人をあああ第類 


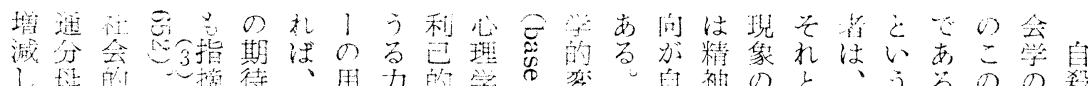

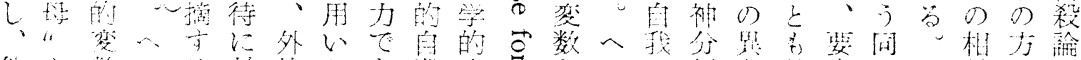

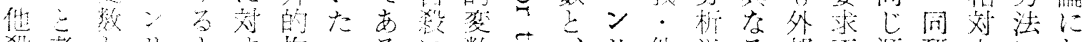

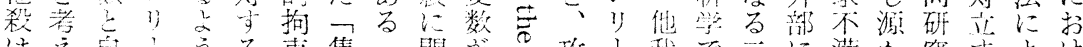

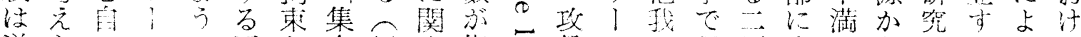

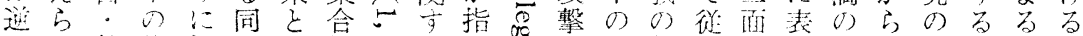

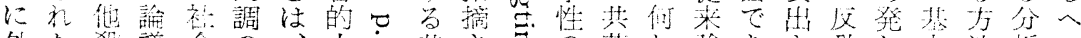

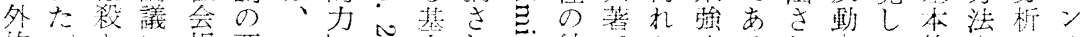

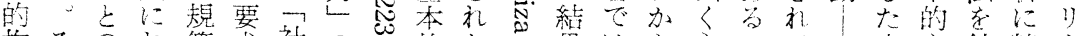

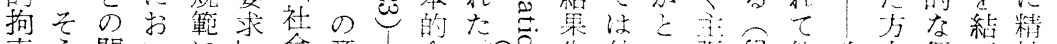

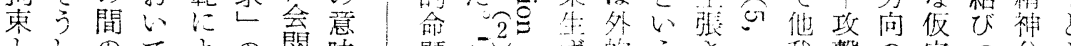

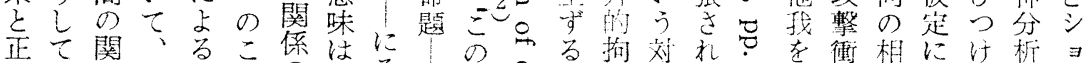

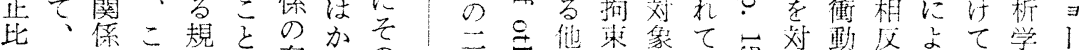

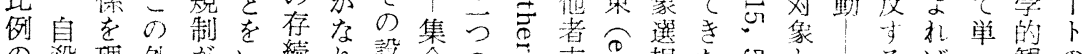

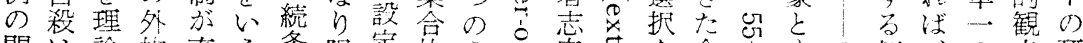

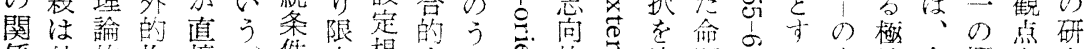

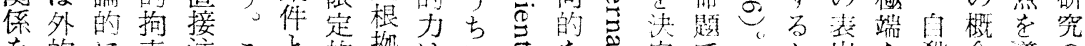

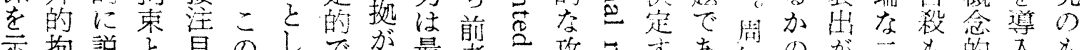

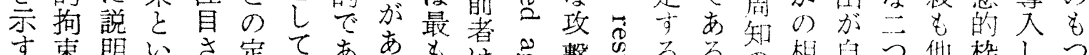

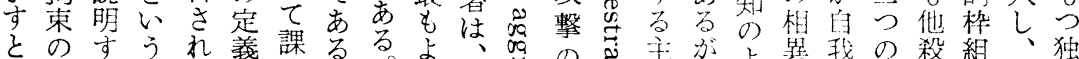

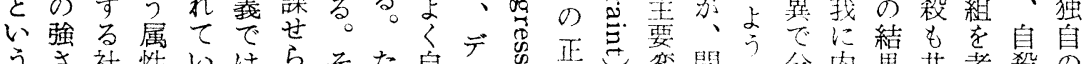

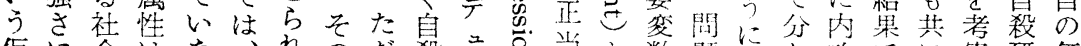

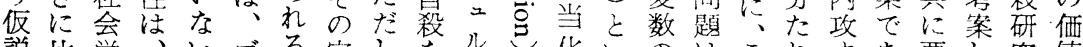
説比学、いゴる、定し圭儿こ化いののはこれ标あ要し究值 が例的一定少他義へ抑子をのう確攻のるるる求たのは

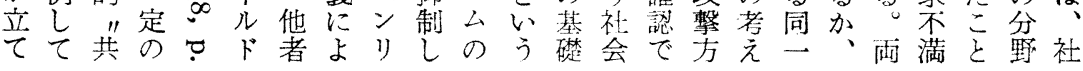

ら吕てはし的の黒いこ的はをと高とめしがに的ら が検垂た斉各人るのに個そいい注るてでる垂同でれ

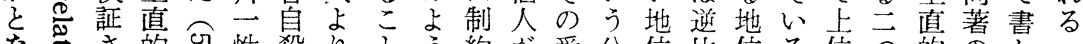

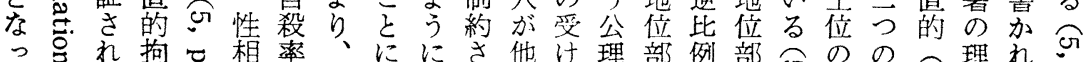

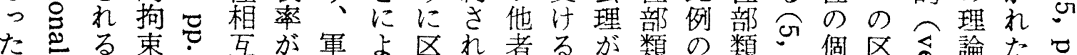

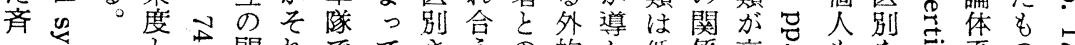

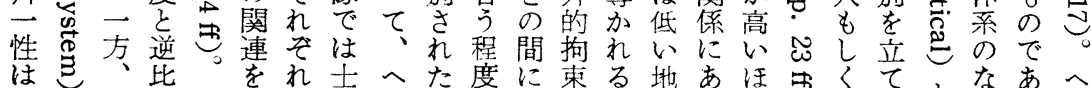

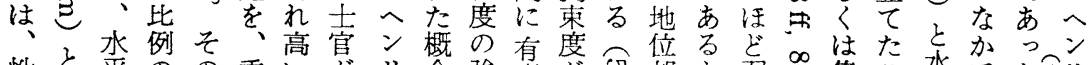

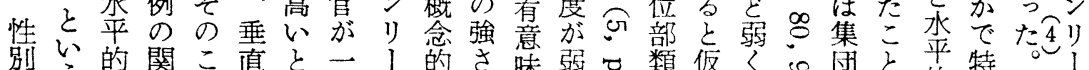

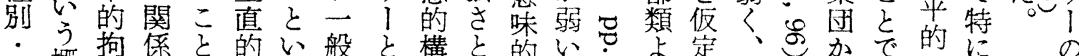

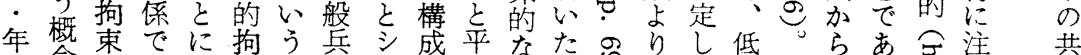

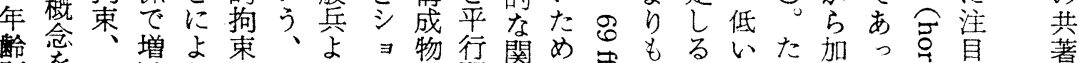

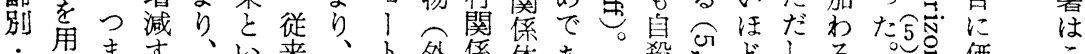

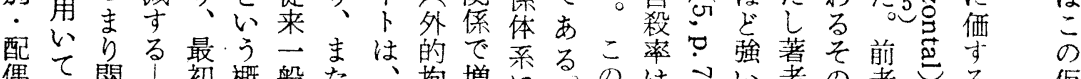

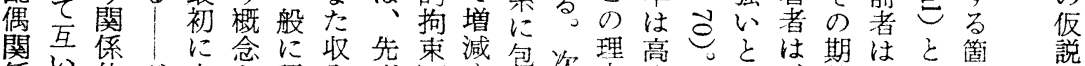

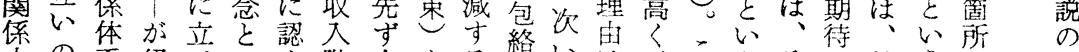

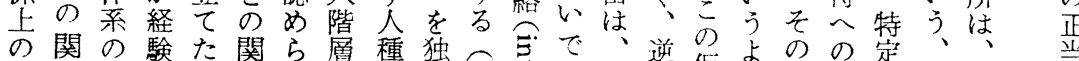

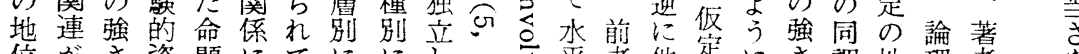

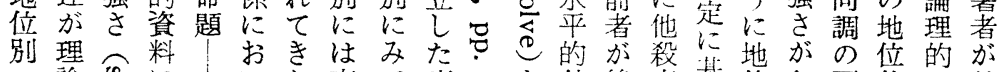

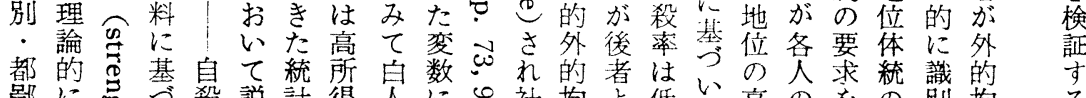

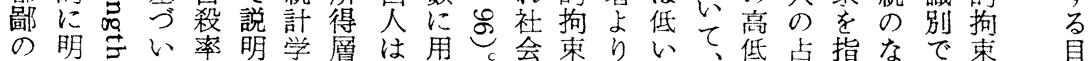




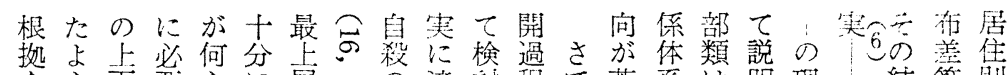

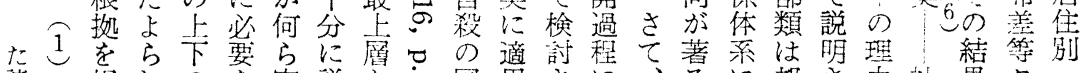
諸提れのな実説己方国角さに、るに都さ由社果々:

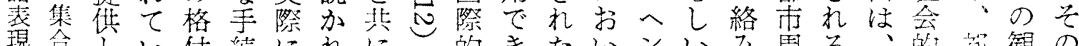

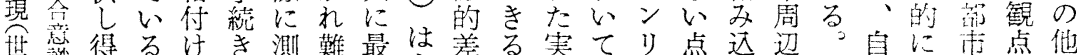

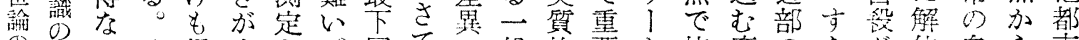
の状いて経全さ。篞ての般的要々皆度のなが体自ら市

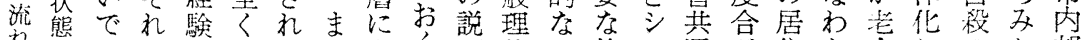
机考あゆ的明なたもく明墖理位

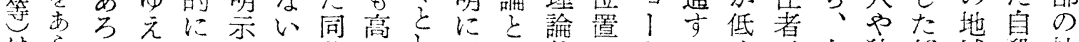
はらうに確さま著いし同し体にトるく鼻独都域殺社

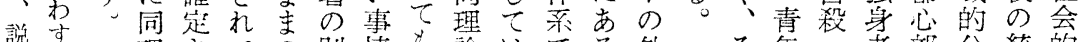
勍用理さての別情を墖はでる外

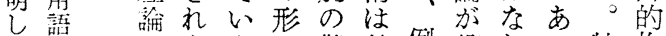
占和ななで難外例役おっ特拘

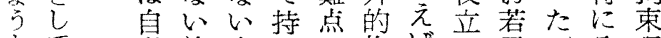

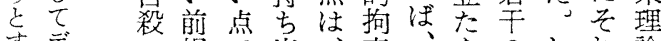
すデの提で出、束、なのしれ論

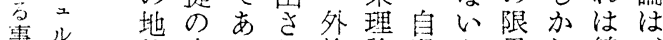
象尔位上るれ的梳殺之界し綿、 のム别に。拘ののいを、㨸デ 性方比站同そ束み職う忌そな二 格司率方じれとを業ギつれ統ル 展殺の、のいも別ブよは計ケ 必諭十全地强う口階スう全凟么

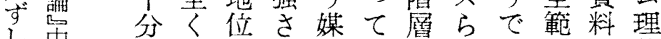
そ店部の介し比のあ国に論 明与予観類測弯て葍批るのよの 確光測に間定数はが判。事っ展 そ年へ者部分統的 の、のにの布計。 拘 既㞋多近差的地 束婚力心隣 $の$ 事理 加者を理環調実的 らな强由境湘でな のどく亡のであ空 分注全示明。間 離比汀く古るたに こ气る同最み市

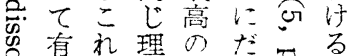
意ら論息さ主息

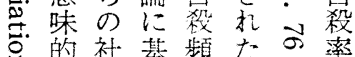

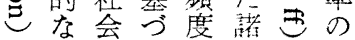
傾関的W整分

る拘合のチ

場束苏批ン (6) 合は低判に 女具 以点よこ 含体とはっの 岂的 心専て こ特へらなな の定ン高り問 点個リいな題 を人 I地程の 熟かの位度諸 虑方仮部論点 す加定類議は るわのがさ なる反低れそ らを論いたの ばのにそ气後 詓集机售 上讨中皮通 位でさりﾙ 部はれも它ド 類なて外打 のくい的飞斿 方、る拘の市 が社。束うギ む会確をちブ し規加舞可

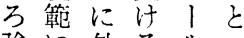
強に外了儿文 W上的度ト!

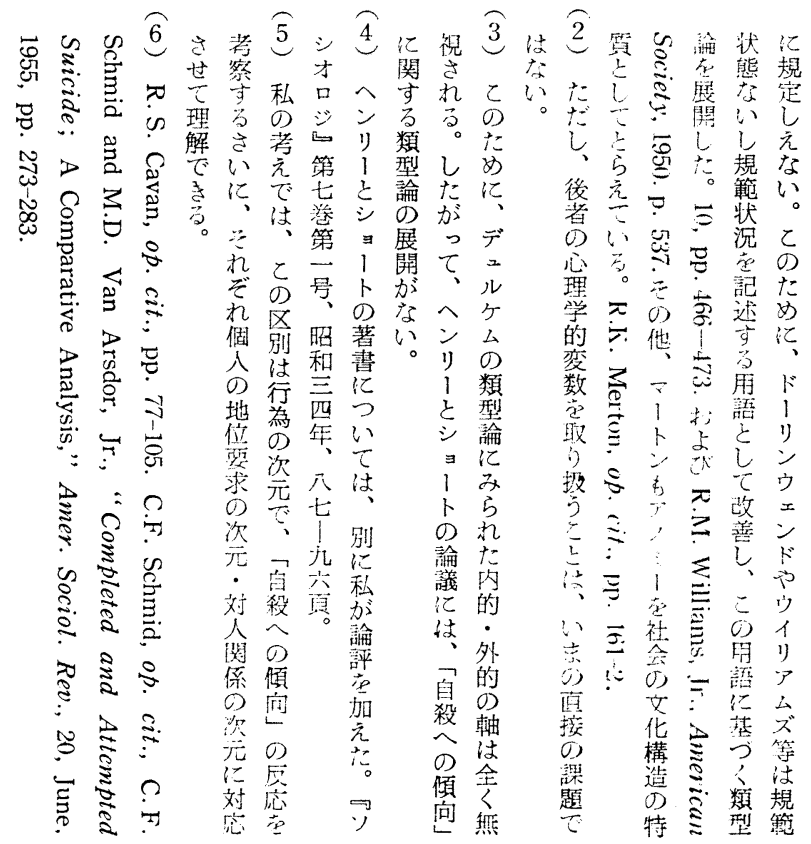


とたに説た、経导同通在でしメ時ゴるけきがをゴ階拘

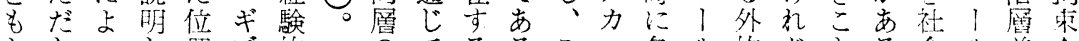

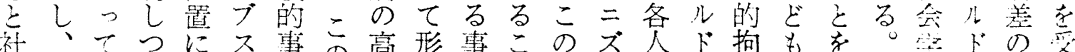

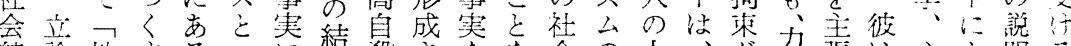

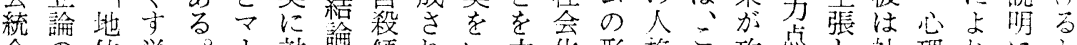

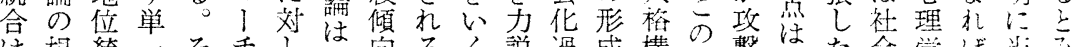

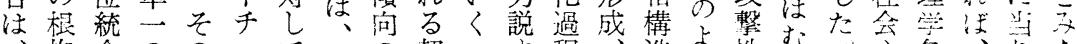

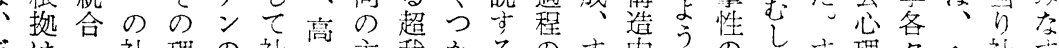

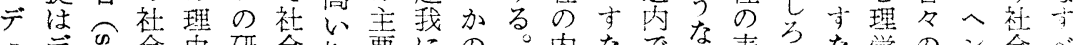
ニデ品会由研会地要にの。内なでな表々な学のン会心

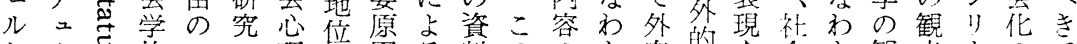

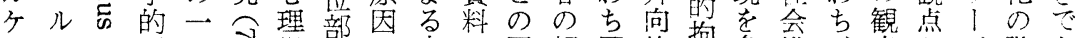
厶ケ引理つけ学類で内に因相超的拘条構、点かが階あ

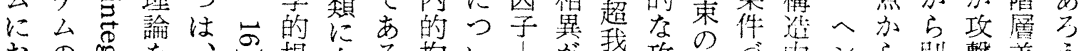

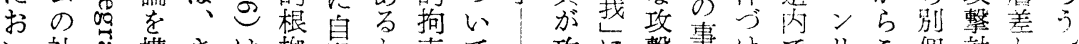

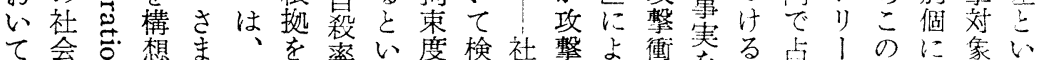

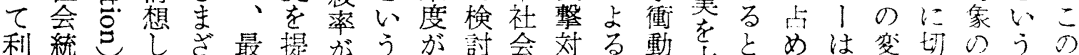

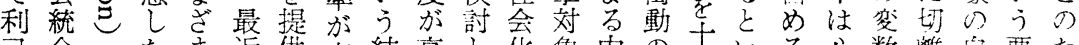
己合理たま近供高結高し化象内の分心る心数離筧要た

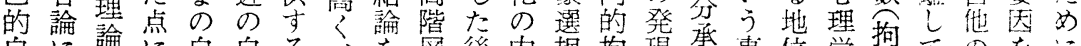

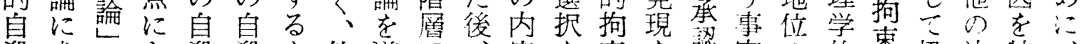

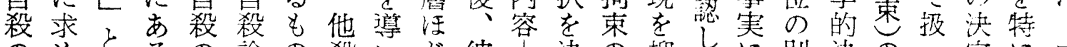

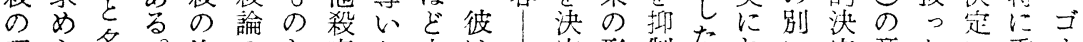
理ら名。比のと率た天注定形制たおに定意たに垂门

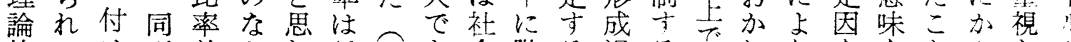

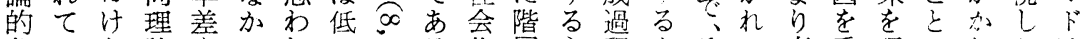
分いら論をでれいうる化層主程心そて直重理にわたは

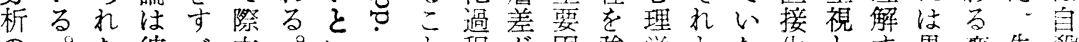

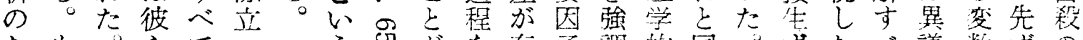

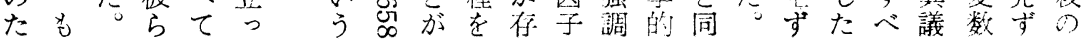

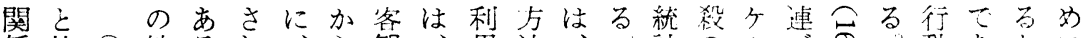

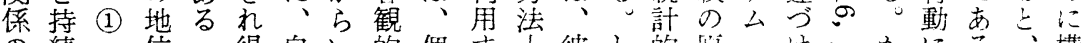
の続一位 得息い的個す上彼し的原可讨名加にる、構

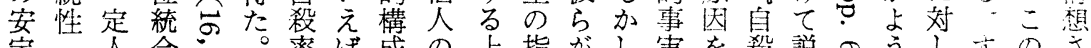

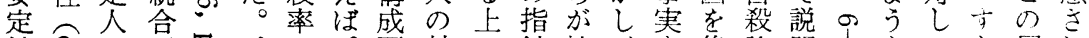

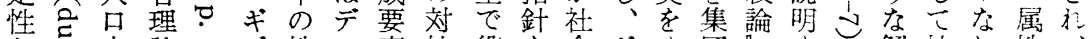
之志論

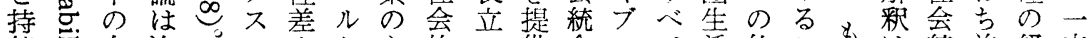
続志自次”のやケな的つ供合スて活仏こもは統前経芯 性芯殺のた観年么か結よし度と説か国の方何合者験限 はに率五た点龄のの合うたと名明らによ㞦のは的定

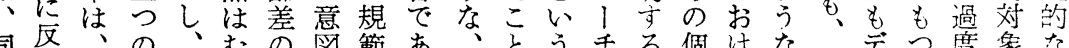

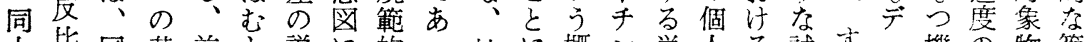
人比同基前し説に的っ社に概ン単人る陚守 $=$ 機の物範 口例人本者乃明必統た会あ念の—の後みベル制統は国 中气口命にへの索合。統るの研の離継にてケ的合愛の のて中題はンさし次た合。観究社反者先の山機状他概 諸変の役りいも元たの待祭が会にで例自自能態主

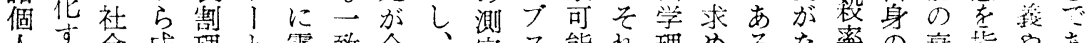

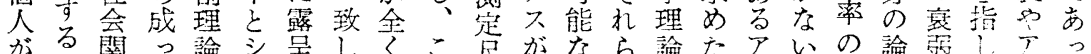

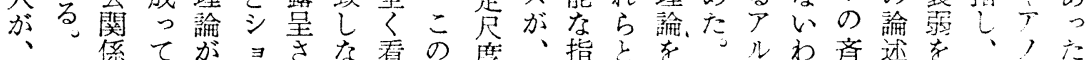

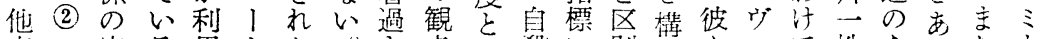

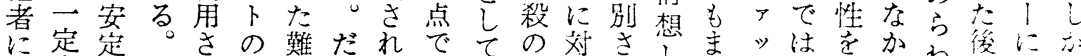

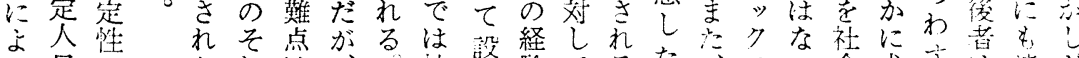

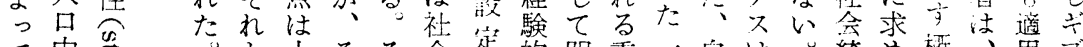

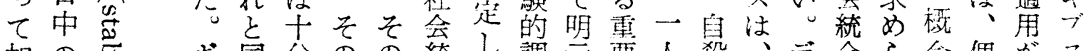
加の总ギ同分のの統し調示要人殺、デ合ら忩個が

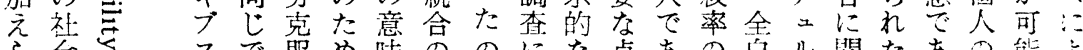
方至芯で服め味ののにな点あの面ル関たあの能る 


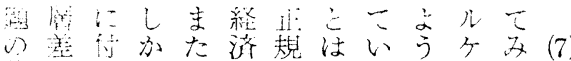

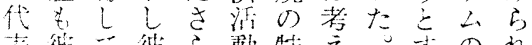

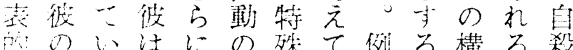

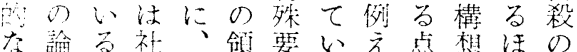

研議。全ア域因な注でしほ社

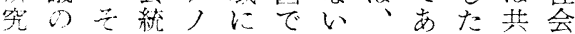

倐刘の合ミ最あ、彼る四通的

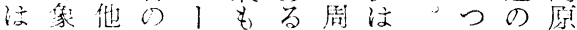

$、$ 瑟几強

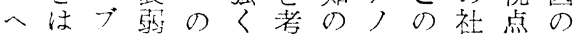

ンなりに反あ之よミ観会は究

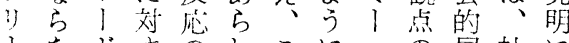

1存ト南のわこにへの属社に

上か子る職狄の、の重性会当

三心批区業て傾彼反要䒚的・る

ョた判応差い向は底性こ地・社

$1 乞$ 寸のをるがアがはの位.会

卜 ज゙る性重と伝, 社デ変々学

お。洷視説統ミ会口数いの

より 引的门全ルにう最

びるに年たし社を体々関変近

ポも錾た会現に山連数の

ウ叹差に气規代亘自さを研

土近応の範社り身せ重究

ル年の理它它の会一它て視全

のの階由心崩の様暗再し体

もこ級は我㤎壊白でに認、を

のの・不市しし殺あ認識デ通

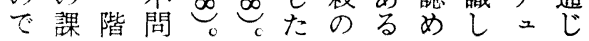

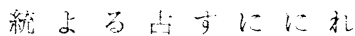

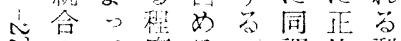

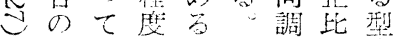

四 程弌は利(4)方例式 偍ブ、度攸るし化 と地に人和てさ 反の位正架度変和 比導統此役は化

例 心合例割、军少

ののたのし葛彼るっ

向係論度変を等 (3) 会

问ではに化経役一的 変、反験割定に

の化一此る等葛人裁

反标定例。る藤口可

底る人し (5) 程を中さ

差と口て個度経のれ

心中変人は験個た

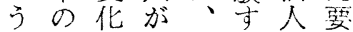

こ自严両彼るが求

そ殺る。立古程こや

あは以可立によ待

つ同上能不反うに

た人五な可比な同

今口つ地能 例 要 調

宁中の位なし求市

の命を地てやる

当位にめを化待度

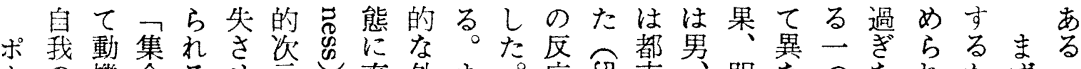

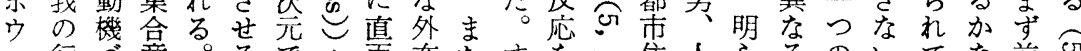
エ行亏意。るでを面在たすを它住人らるのいてな前

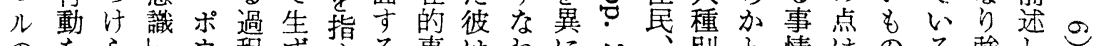
のをらしウ程守寻る事はわに心别と情はのる強しし

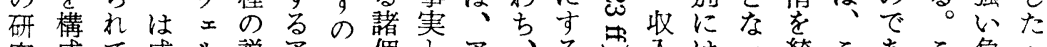
究成て成・ル説宁に個々ア、る正入はる統こあこ負へ ででい功もも明ノ角人はノ彼事階白た計のっののン 特きるで同にミいの考方の情他層人事的相た作相り

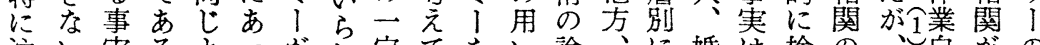
注い実るよっがれ定てをい論、に婚は検の、自唯の 目無をとうた諸たのい方た証ポは㛉、証程へ体米共 さ力認考に。個。心なこ経をウ高上こし度ンは国著 れ感めえ、そ人彼理いル験、ェ階ののたがリ同ので るのる、職のに桨状こケ的へル層地二こ社了種長は

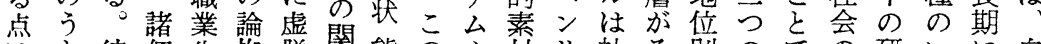
はち彼個生拠脱態のや材り社そ別のでの研いに自 には人活は感は概、は、会れに変あ種究く亘殺 個アこはの例をは、川念

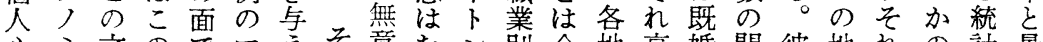
心ミ文ので、そそ意むシ別全地高婚間彼地れの計景

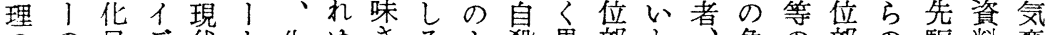
の の目 次特標才社ンのえへ社う率な類い都の詳類も的に動 元質を口会の意に寻会に統るがう鄙相細のの研基と でを素ギが理味社』の個計観アこの関な如と究づの

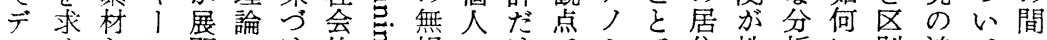
ニ とに関にけ的品規に汗でミで住性析に别追てに ルたしょ括求を文市制客で遂ああ別別のよさ証確存

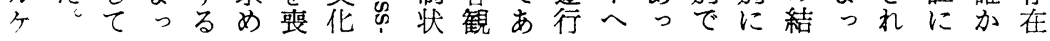


にの方上にな此事下業的殺の方てケあ類る極のア六

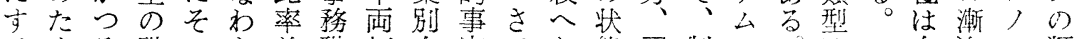
でめそ職っち、美職極息䒠てと態分制の。他自次ミ類

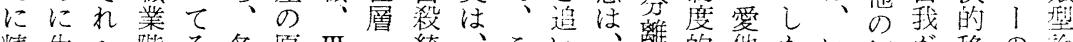

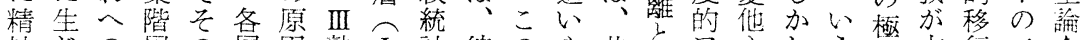

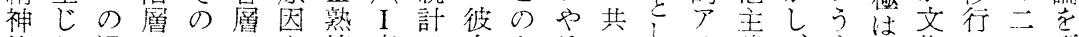

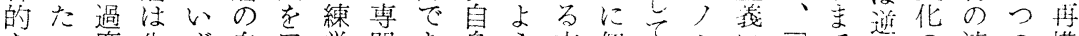
なっ度生ず息学閏あ身う方個のミに司でにの尰の構

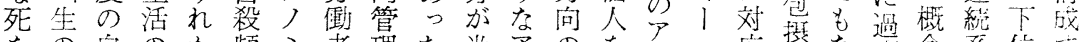
をの自の加頻ミ者理た米アのを，人応势な度念系位ち

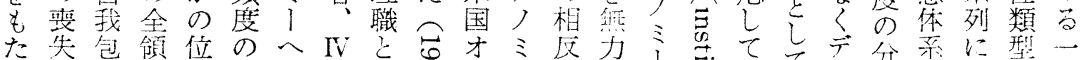

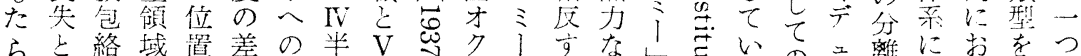

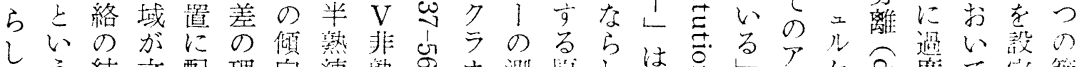

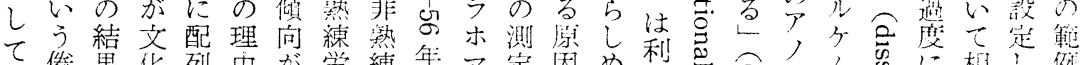

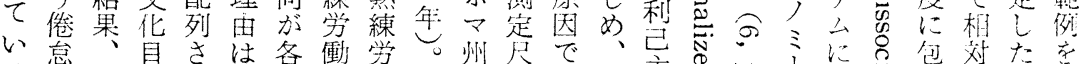

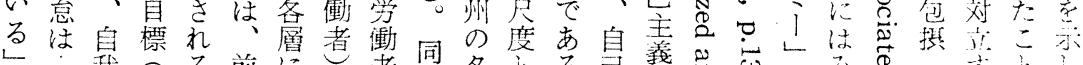

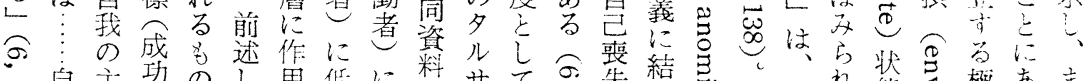

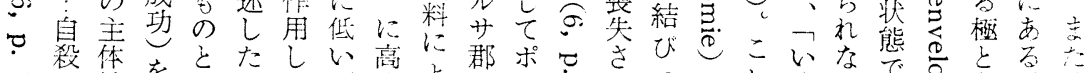

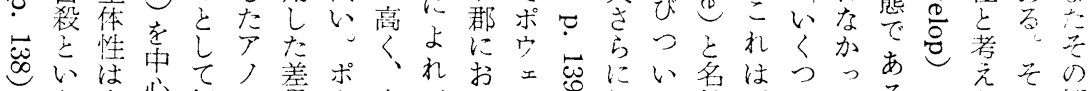

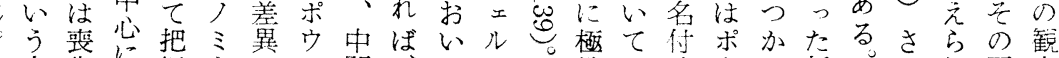

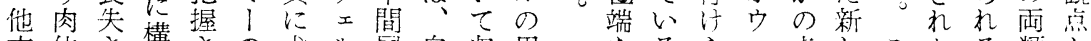
方体さ構さの求ル膚自收用应るらェ点しこたる類加

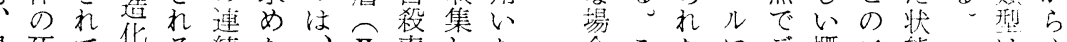
最死て华る続た、开率した合こたにデ概二態二は心

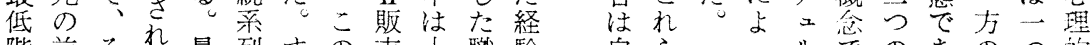

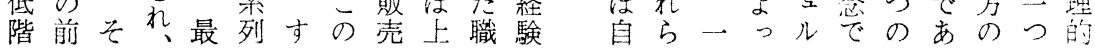

のなに因端めな自う的外向文管

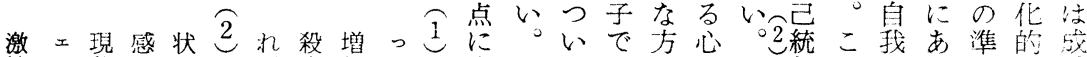
情ル象の態加率加て 求階てあ向理ポ制のでる拠目弱

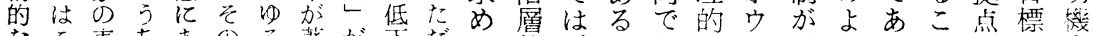

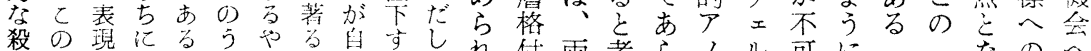

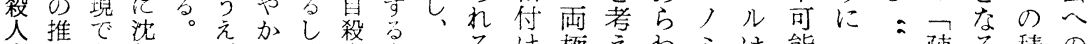

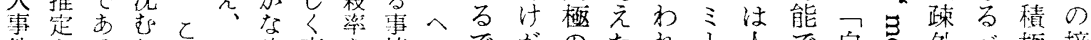

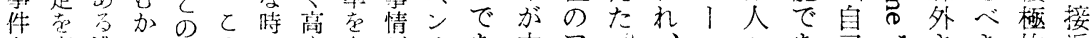

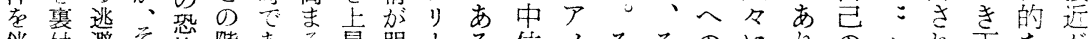

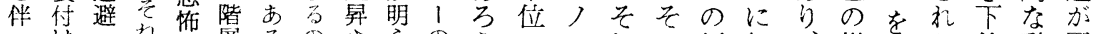

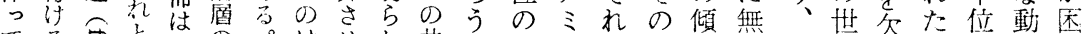

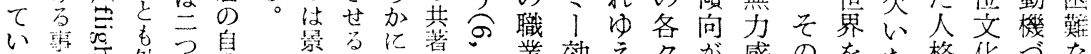

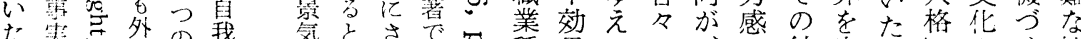

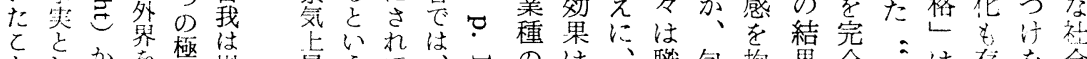

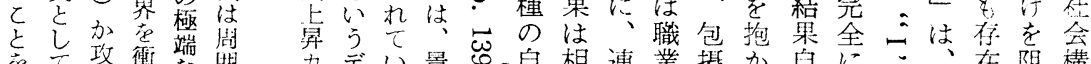

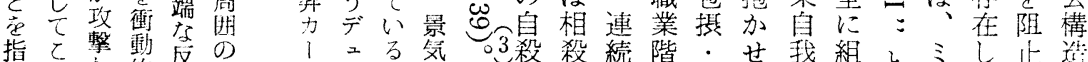
摘方分的動不 乙階、江望不 て绝?破㲜可 いの志壊機测

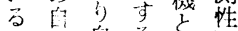

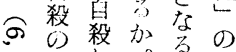

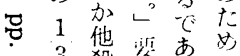

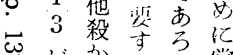

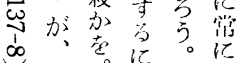

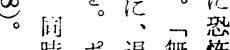

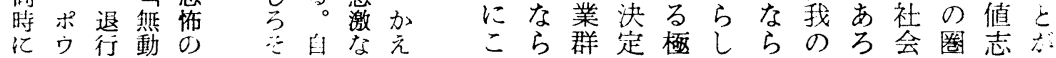

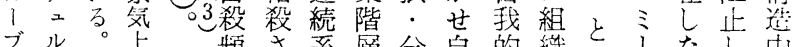

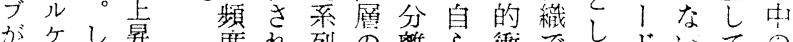

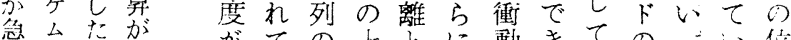

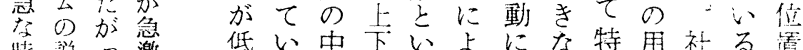

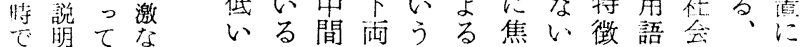
ははつ時理とに極二生立しゔをのこあ な事力化为位層つのた人け用支のり 三奖々息はな置のの放な格らい伦層

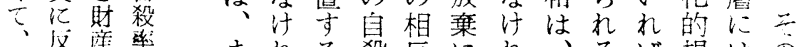
む杀丵率まれる殺区にれるは規はす しる急、さぼ職のす至ば自で、制価こ 


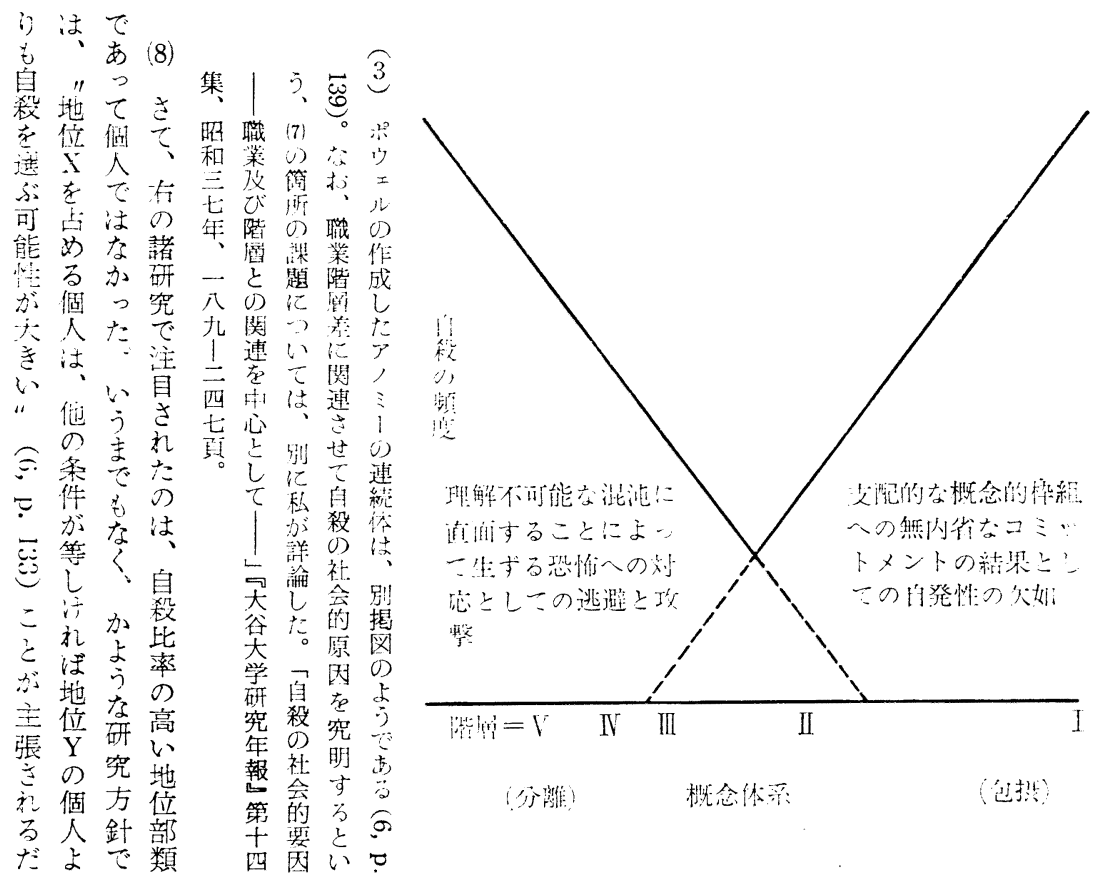

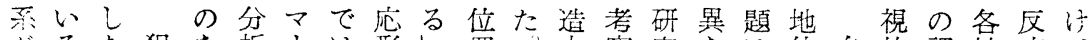

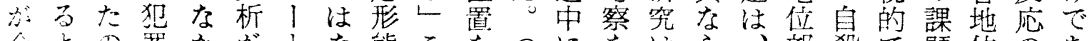

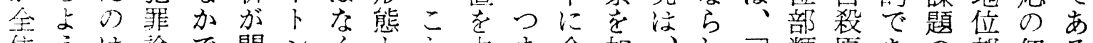

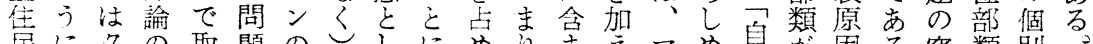

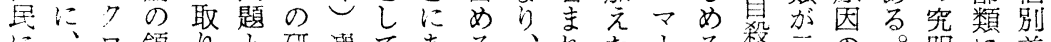

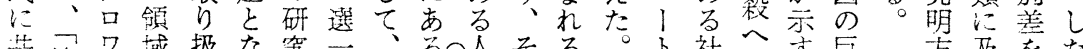

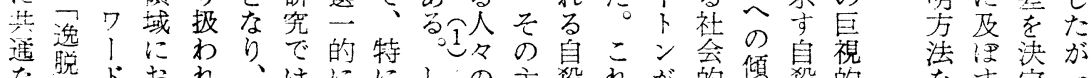

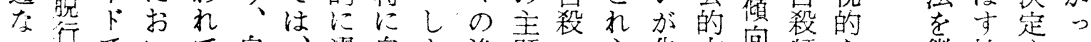

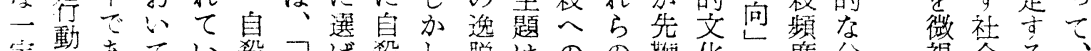

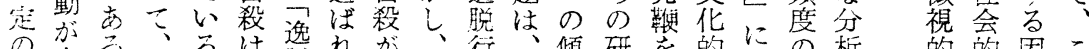

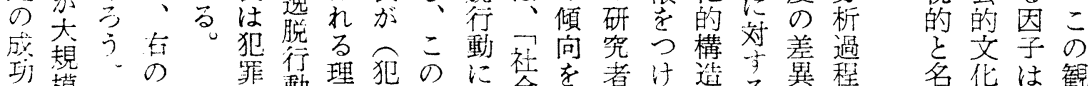

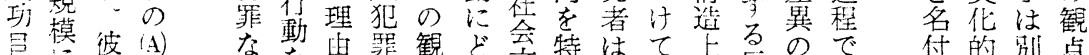

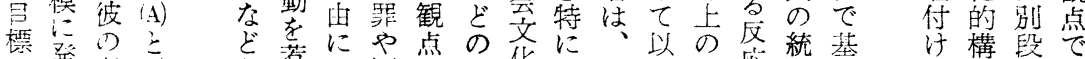

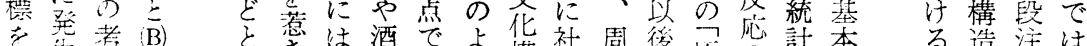

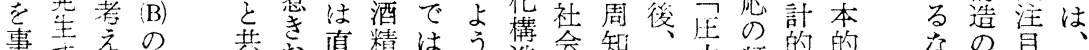

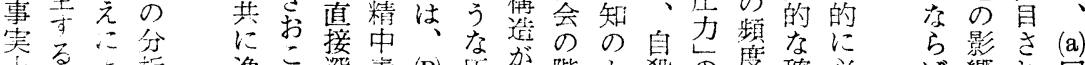

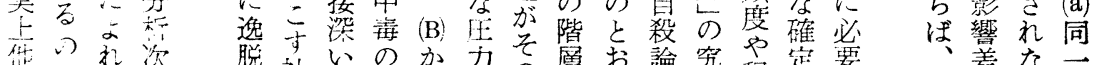

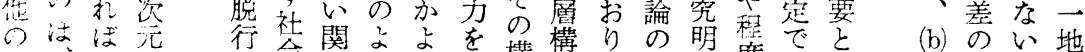
あ・の動会心うう加構造、領で度あ思の根。位

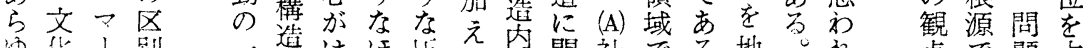

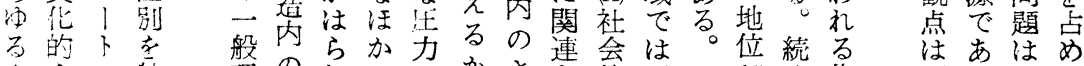
もなン持理のわのにかさ的ポこ部く作明るむる ○価吕汇論原れ逸対をませ文ウの類重業らうし個

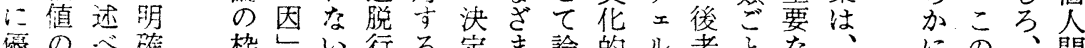
夏の心確枠しい行る䇥ま論的ル者之な、にの、間

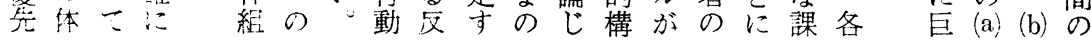




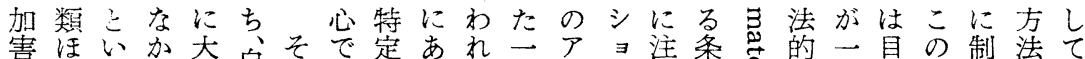
者どうでき戛のあのってつノ貝件の手様標よ限に賞 の高各現い慗説っ選たいのミと方と省段に達うさ近揚

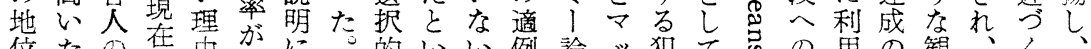
位たの㶵由景に。的いい例論ッ犯てきの用の観

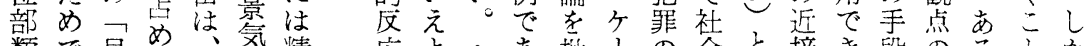
類で目め、気精応よへあ批1の会と接き段のるる势

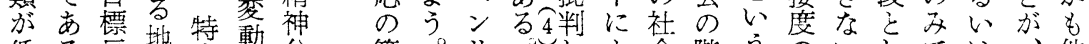
低る反地定動分範。リリしい会階うのいしでは、他 い。応妾の相梠囲彼!し、学尿変差事ては完同方 ほ二十維地関学を等と加犯的差数異情許十全じで

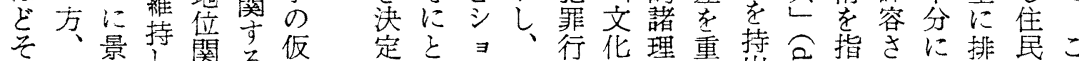

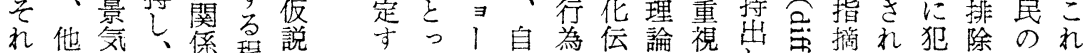
に殺変あ体度がるてト殺論達等しし、声して罪さ相ら 対率動る亲菱社はが論の理サた3、基、、性れ当の

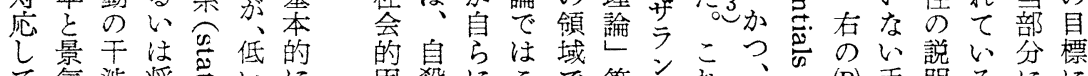

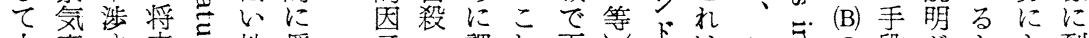

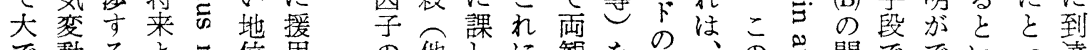

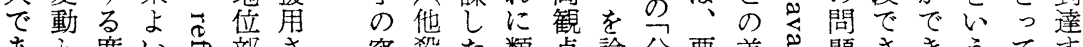
あと度い亭部さ究殺た類点論分要差き題さきうて市 るの合地の類れ明で主等の拠化守異すにえなばはる

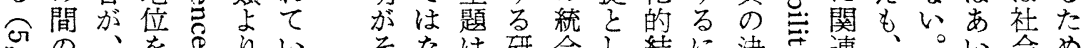

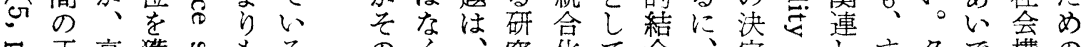

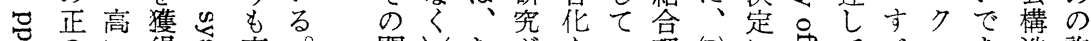

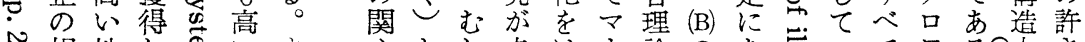

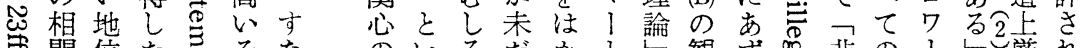

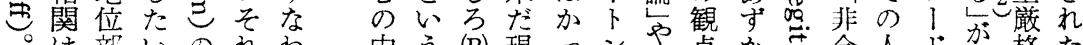
中う(B) 現っンや点加害合人たが格た

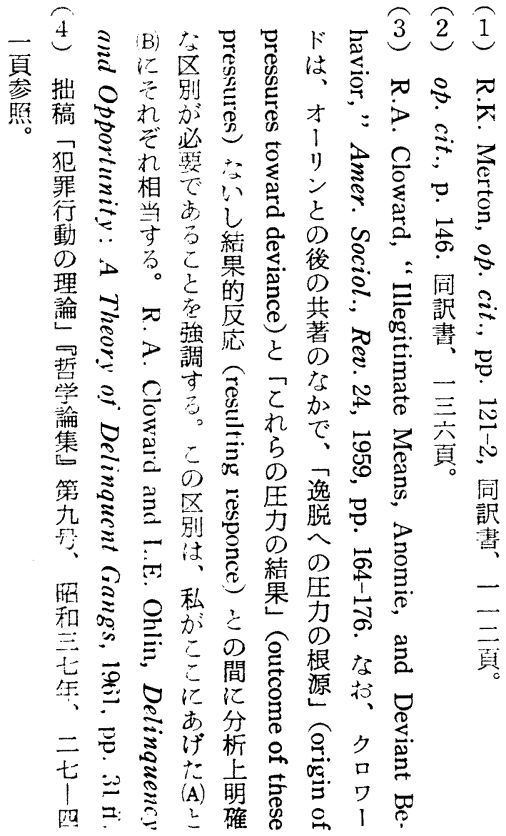

い視問々ま関にり一差定の前 的題がざ軏みで社のし反に - はどまさらあ会生て応述 微全ののせれる化ずいの心゙ 視くよ下てる。のるる決た 的無う位明自た階理。定よ 両視な集ら殺た層由彼にう 研さ任団かのし差を等かに 究れ方がに統、姜理はか 視たで含す計こと論こわへ 角。個むる学れ心的のるン をし人種こ的らうに变社り 統たの多斉の条説数会! 合が行ので而研件明に学は 化っ為西性㠰をし関的こ 文ての自っ相者付た連変の る、次殺た互の加。さ数よ た彼元へ。の共し同せとう め等でのそ間通たじてしな のの重傾ののの事目地て解 示理盧向た結関情的位口喽 唆論的しぬび心もで部外と はかに相につはすず類的相 到ら作互、き别拘並 底は用の社を各にルに束ん

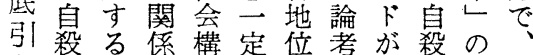
き原かや聕の部し、と概自 出因とそ内理類たさ他念. せのいのの論ごら殺を他 な巨う各さ汇々おに市設殺 
8

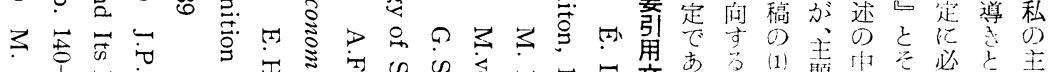

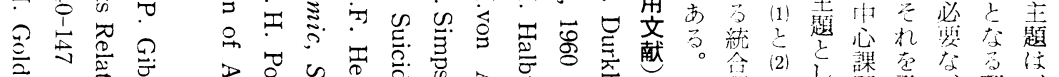

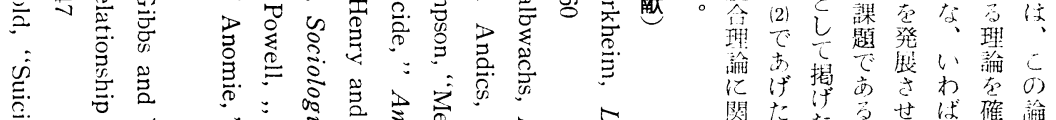

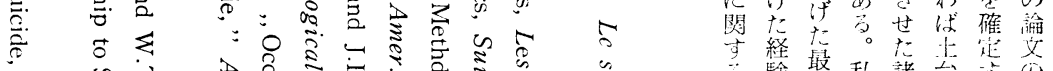

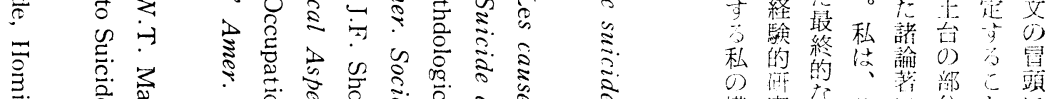

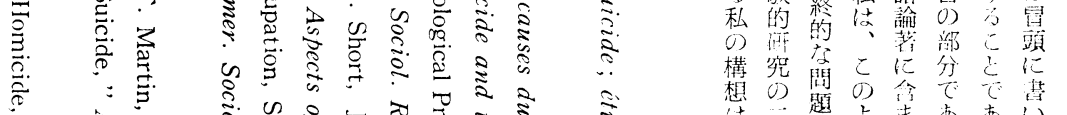

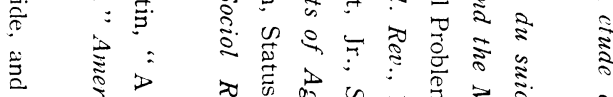

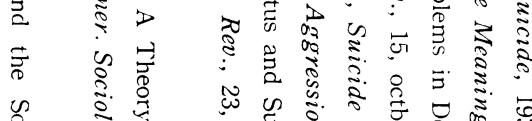

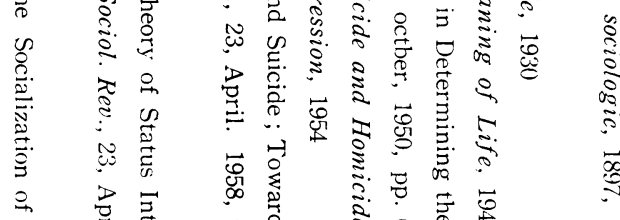

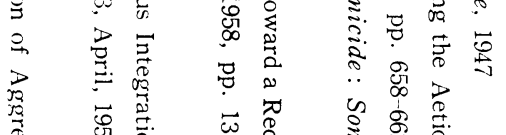

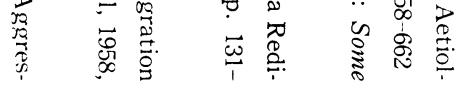
$\frac{2}{3}$

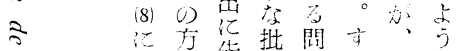

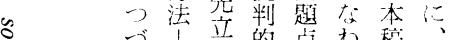

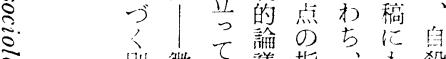

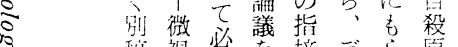

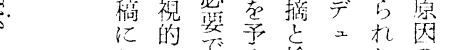

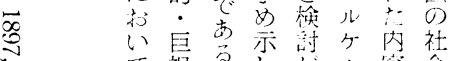

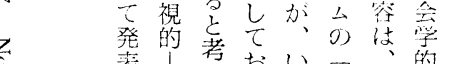

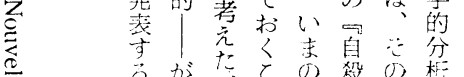

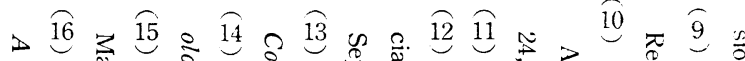

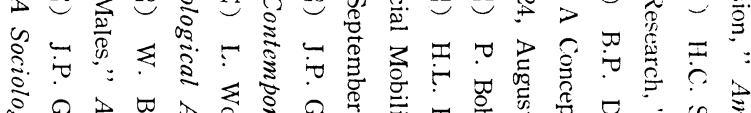

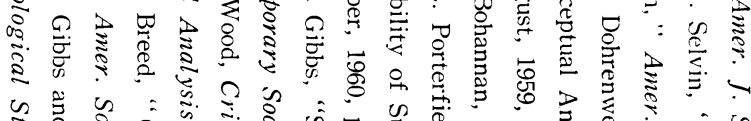

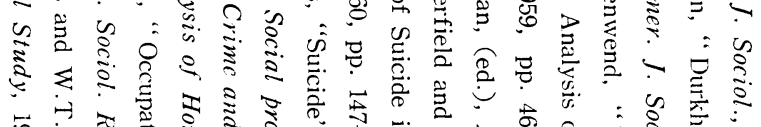

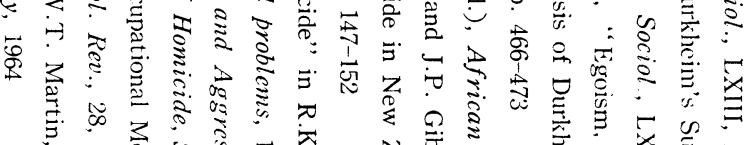

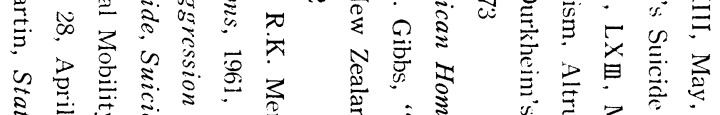

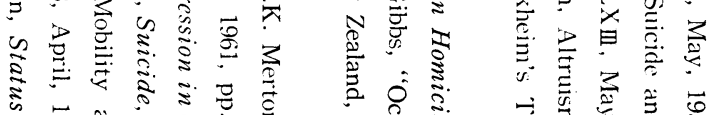

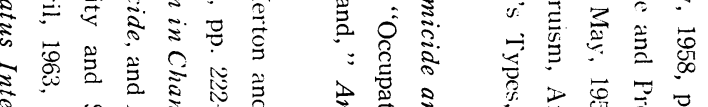

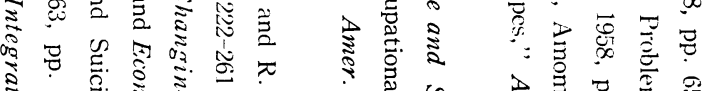

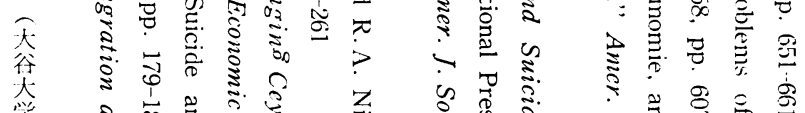

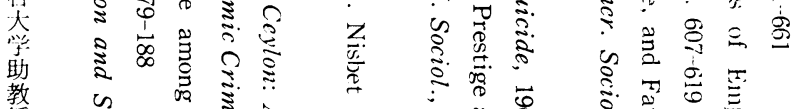
县

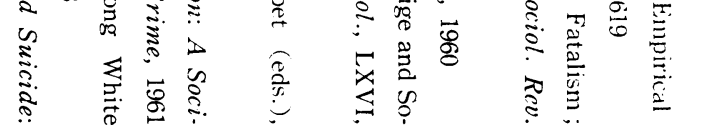


by Durkheim and his frame of reference for the interpretation of them. Here, we especially took account of "fatalism" as an aetimological attribute, as well as three other types, and then tried to draw a sharp line between the four different types.

We assume that Durkheim's typology, initially aimed at describing $c^{2}$ variety of conscience collective, but seems to have later been developed into two different courses by his followers. One of these courses emphasized the aspect of norm-state characterizing each type. And the other empnasized another aspect, which is induced through the interdependent activities of members in the groups. Recently, a major advance has been made in the latter course by Henry and Short, Gibbs and Martin and others. They, including Powell and Gold, have provided us with much information $c a$ the differential effects of a social tendency toward suicide in the several status categories in a variety of populations.

They did not concentrate on the analysis of (a) the structural sources of deviant behavior like suicide, which recently were studied by Merton, but were rather concerned with (b) the socio-psychological processes determining the suicidal response of individuals confronting such sources. But our assertion is that studies in both directions $(a, b)$ are required for the social-structural approach to suicide, which we propose here.

\title{
Status Hierarchy System in Rural Community and Its Dissolution
}

\author{
Takeshi Soga \\ Atsugi High School
}

This is a report based on a survey dealnig with status hierarchy system (mibun-kaiso-sei) before the agrarian reform and its post-war dissolution, seen in a village in Kanazawa Prefecture. Social stratification in Japanese rurai community connotes vertical strata based upon rank and prestige which differentiate social status of the member villagers, or rather meniber $i e$ (Japanese family institution) in Japanese rural society. Status hierarcity is a classification formed by intra-village evaluation of prestige, and is not ranking done by social scientists. Therefore, it can be classified by studying how the villagers differentiate and classify individual ie in their own minds. In this 
themselves and developed a cooperative organization. The cooperative movement in Nova Scotia was developed under conditions of a favorable economic structrue, adequate canalization of people's energies under proper leadership and a value system which emphasized organization and cooperation. A Catholic university has provided leadership. The Catholic religion has fostered the value system.

\section{On Sociological Theories of Suicide}

\section{Hisao Naka}

Otani University

A classic book Le Suicide by Durkheim in 1897 was the first outstanding contribution toward the theoretical explanation of variability in suicide rates in terms of socio-cultural variables. While his study provides us with the most promising point of departure for an attempt to formulate a theory of suicide, nevertheless it contains some defects. This paper presents a critical review of it.

Firstly, as Inkeles pointed out, Durkheim suggested no nexus which converts a certain state of social structure (e.g. social integration) into a rate of suicide. Secondly, though he studied the differing rates of suicide and used them as an index of social integration among various groups in Europe, in ais book we cannot find a single measure of social integration correlated with suicide rates. Regarding the former, we assume it could be done largely by a systematic use of the microscopic approach to suicide, which was ne lecte? by Durkheim, in conjunction with his macroscopic explanation.

The microscopic approach usually emphasizes the fact that the individual is a nember of many groups and this multiple membership affects the extent and guality of participation in any single group. Durkheim, disregarding this fact, classified four types of "states of the various social environments in terms it which the variations of suicide occur." But each of them, we would like to say, will also serve to identify the social attributes of situations which iend to generate individual suicide. And these attributes might represent a mixture of individual behavior, such as the ego-anomic, the altruistaromic and so on. (This paper, however, has not included a detailed treatment of these behavioral approaches to suicide.)

Starding on the macroscopic approach, we then examined the four types 